\title{
2019 Offshore Wind Technology Data Update
}

Walter Musial, ${ }^{1}$ Philipp Beiter, ${ }^{1}$ Paul Spitsen, ${ }^{2}$

Jake Nunemaker, ${ }^{1}$ Vahan Gevorgian, ${ }^{1}$

Aubryn Cooperman, ${ }^{1}$ Rob Hammond, ${ }^{1}$ and

Matt Shields ${ }^{1}$

${ }^{1}$ National Renewable Energy Laboratory

${ }^{2}$ U.S. Department of Energy

NREL/TP-5000-77411

October 2020 


\section{Table of Contents}

\begin{tabular}{|l|l|l|}
\hline 1 & Data and Methodology & $3-6$ \\
\hline 2 & U.S. Offshore Wind Data & $7-25$ \\
\hline 3 & Global Offshore Wind Data & $26-36$ \\
\hline 4 & Global Floating Offshore Wind Data & $37-47$ \\
\hline 5 & 2019 Offshore Wind Technology Trends & $48-62$ \\
\hline 6 & 2019 Offshore Wind Cost Data & $63-70$ \\
\hline 7 & References & $71-77$ \\
\hline 7 & Notice and Acknowledgments & 78 \\
\hline
\end{tabular}


Data and Methodology 


\section{Data Sources}

This update draws data from the U.S. Department of Energy's (DOE's) National Renewable Energy Laboratory's (NREL's) internal offshore wind database, which is built on internal research and a wide variety of data sources, including peer-reviewed literature, press releases, industry news reports, manufacturer specification sheets, and global offshore wind project announcements. For the database, NREL has verified and sourced data from the following publications:

- The 4C Offshore Wind Database (4C Offshore 2020)

- Bloomberg New Energy Finance (BNEF) Renewable Energy Project Database (BNEF 2020)

- 4C Offshore Vessel Database (4C Offshore 2020)

- Wood Mackenzie Wind Turbine Trends (Wood Mackenzie 2020).

- Link to 2019 Data Table 


\section{Scope and Pipeline Definitions}

- $\quad$ This work defines the offshore wind project pipeline as potential offshore wind development indicated by developer announcements or by areas made available for offshore wind development by regulatory agencies.

- The scope of this report covers the global fleet of projects in the pipeline through December 31, 2019.

- This report also covers recent developments and events in the United States through March 31,2020 , projects that have been completed before March 31, 2020, and selectively covers significant industry events through August 2020.

- $\quad$ Any estimates of capacities and project dates are shown as reported by project developers or state/federal agencies.

- $\quad$ All dollar amounts are reported in 2019 U.S. dollars, unless indicated otherwise.

- In this analysis, the U.S. pipeline capacity includes the sum of project-specific capacities and the undeveloped lease area potential capacities based on a project density of 3 megawatts $(\mathrm{MW}) / \mathrm{km}^{2}$.

- $\quad$ For further discussion on methodology and data sources, please refer to the "2018 Offshore Wind Technologies Market Report" (Musial et al. 2019). 


\section{Project Pipeline Classification System}

The following classification was used for global and U.S. pipeline capacity estimates (see Musial et al. 2019 for more details). The offshore wind pipeline is based on publicly available information.

\begin{tabular}{|c|c|c|c|}
\hline Step & Phase Name & Start Criteria & End Criteria \\
\hline 1 & Planning & $\begin{array}{l}\text { Starts when a developer or regulatory agency initiates the formal site } \\
\text { control process }\end{array}$ & $\begin{array}{l}\text { Ends when a developer obtains control of a site (e.g., through competitive auction } \\
\text { or a determination of no competitive interest in an unsolicited lease area [United } \\
\text { States only]) }\end{array}$ \\
\hline 2 & Site Control & $\begin{array}{l}\text { Begins when a developer obtains site control (e.g., a lease or other } \\
\text { contract) }\end{array}$ & $\begin{array}{l}\text { Ends when the developer files major permit applications (e.g., a construction and } \\
\text { operations plan for projects in the United States) or obtains an offtake agreement }\end{array}$ \\
\hline 3 & $\begin{array}{l}\text { Permitting }= \\
\text { Site Control + Offtake } \\
\text { Pathway }\end{array}$ & $\begin{array}{l}\text { Starts when the developer files major permit applications (e.g., a } \\
\text { construction and operations plan or an offtake agreement for } \\
\text { electricity production) }\end{array}$ & $\begin{array}{l}\text { Ends when regulatory entities authorize the project to proceed with construction } \\
\text { and certify its offtake agreement }\end{array}$ \\
\hline 4 & Approved & $\begin{array}{l}\text { Starts when a project receives regulatory approval for construction } \\
\text { activities and its offtake agreement }\end{array}$ & $\begin{array}{l}\text { Ends when a sponsor announces a "financial investment decision" and has signed } \\
\text { contracts for construction work packages }\end{array}$ \\
\hline 5 & Financial Close & $\begin{array}{l}\text { Begins when a sponsor announces a financial investment decision and } \\
\text { has signed contracts for major construction work packages }\end{array}$ & Ends when a project begins major construction work \\
\hline 6 & Under Construction & Starts when offshore construction is initiated & $\begin{array}{l}\text { Ends when all turbines have been installed and the project is connected to and } \\
\text { generating power for a land-based electrical grid }\end{array}$ \\
\hline 7 & Operating & $\begin{array}{l}\text { Commences when all turbines are installed and transmitting power to } \\
\text { the grid; commercial operation date (COD) marks the official transition } \\
\text { from construction to operation }\end{array}$ & $\begin{array}{l}\text { Ends when the project has begun a formal process to decommission and stops } \\
\text { feeding power to the grid }\end{array}$ \\
\hline 8 & Decommissioned & $\begin{array}{l}\text { Starts when the project has begun the formal process to } \\
\text { decommission and stops transmitting power to the grid }\end{array}$ & $\begin{array}{l}\text { Ends when the site has been fully restored and lease payments are no longer being } \\
\text { made }\end{array}$ \\
\hline 9 & On Hold/Cancelled & $\begin{array}{l}\text { Starts if a sponsor stops development activities, discontinues lease } \\
\text { payments, or abandons a prospective site }\end{array}$ & Ends when a sponsor restarts project development activity \\
\hline
\end{tabular}


U.S. Offshore Wind Data 


\section{Breakdown of U.S. Offshore Wind Pipeline $(28,521 \mathrm{MW})$}

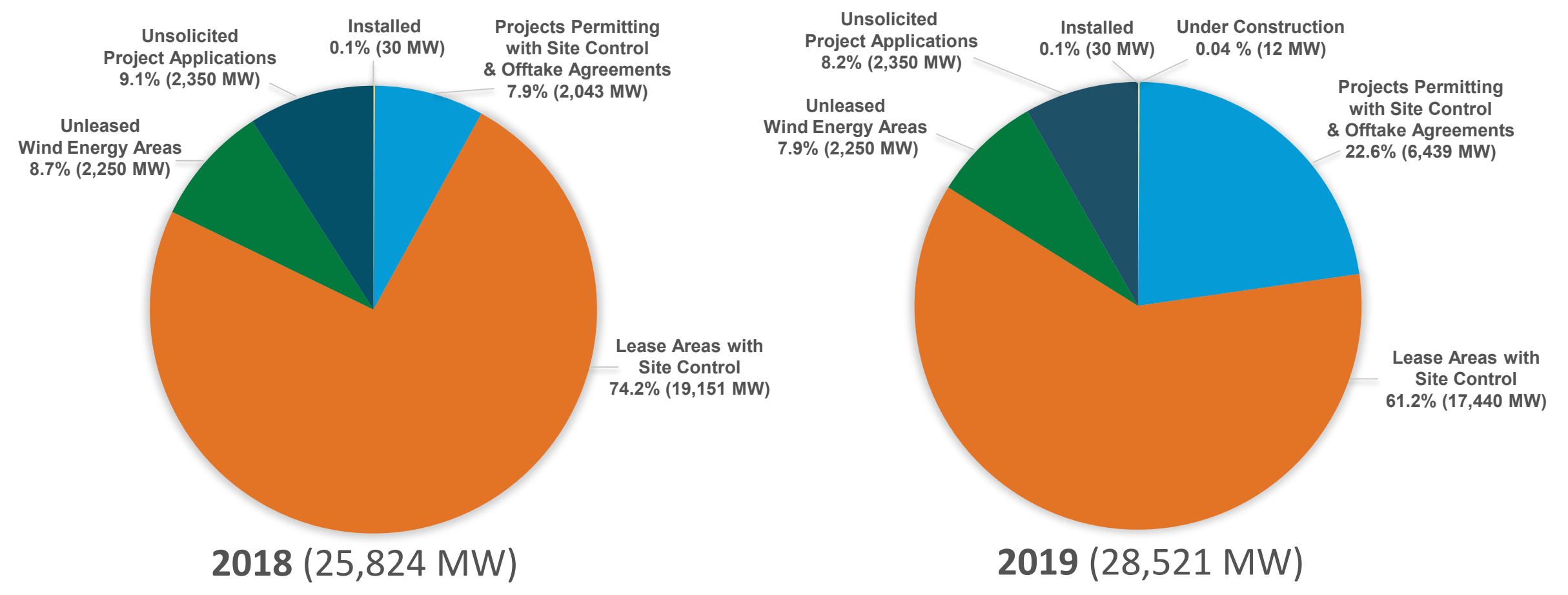

- From 2018 to 2019, U.S. projects with site control and offtake agreements grew over $200 \%$.

- Up to $61 \%$ of the U.S. offshore wind pipeline is still made up of unspecified lease area potential. 


\section{U.S. Offshore Pipeline by Status}

\begin{tabular}{|c|c|c|c|c|c|c|c|c|}
\hline States & Project Name & $\begin{array}{l}\text { Commercial } \\
\text { Operation Date }\end{array}$ & Operating (MW) & $\begin{array}{c}\text { Under } \\
\text { Construction (MW) }\end{array}$ & $\begin{array}{l}\text { Permitting } \\
\text { (MW) }\end{array}$ & Site Control (MW) & $\begin{array}{l}\text { Planning } \\
\text { (MW) }\end{array}$ & Totals (MW) \\
\hline Maine & New England Aqua Ventus I & 2023 & & & 12 & & & 12 \\
\hline \multirow{7}{*}{ Massachusetts } & Vineyard Wind & 2023 & & & 800 & & & \multirow{7}{*}{8,220} \\
\hline & Vineyard Wind Residual & TBD & & & & 421 & & \\
\hline & Mayflower Wind & 2025 & & & 804 & & & \\
\hline & Mayflower Wind Residual & TBD & & & & 747 & & \\
\hline & Beacon Wind & TBD & & & & 1,564 & & \\
\hline & Liberty Wind & TBD & & & & 1,607 & & \\
\hline & Bay State Wind & TBD & & & & 2,277 & & \\
\hline \multirow{2}{*}{ Rhode Island } & Block Island Wind Farm & 2016 & 30 & & & & & \multirow{2}{*}{430} \\
\hline & Revolution Wind & 2023 & & & 400 & & & \\
\hline \multirow{2}{*}{ Connecticut } & Revolution Wind & 2023 & & & 304 & & & \multirow{2}{*}{1,108} \\
\hline & Park City Wind & 2025 & & & 804 & & & \\
\hline \multirow{4}{*}{ New York } & South Fork & 2023 & & & 130 & & & \multirow{4}{*}{3,410} \\
\hline & Empire Wind & 2024 & & & 816 & & & \\
\hline & Empire Wind Residual & TBD & & & & 1,584 & & \\
\hline & Sunrise Wind & 2024 & & & 880 & & & \\
\hline \multirow[b]{2}{*}{ New Jersey } & Ocean Wind & 2024 & & & 1,100 & & & \multirow[b]{2}{*}{4,447} \\
\hline & Ocean Wind Residual & TBD & & & & 847 & & \\
\hline Delaware & Garden State Offshore Energy & TBD & & & & 1,050 & & 1,050 \\
\hline \multirow{3}{*}{ Maryland } & Skipjack & 2023 & & & 120 & & & \multirow{3}{*}{1,086} \\
\hline & MarWin & 2023 & & & 248 & & & \\
\hline & MarWin Residual & TBD & & & & 718 & & \\
\hline \multirow{2}{*}{ Virginia } & Coastal Virginia Offshore Wind & 2020 & & 12 & & & & \multirow{2}{*}{2,652} \\
\hline & Dominion & TBD & & & & 2,640 & & \\
\hline \multirow{3}{*}{ North Carolina } & Kitty Hawk & TBD & & & & 1,485 & & \multirow{3}{*}{3,735} \\
\hline & Wilmington East Wind Energy Area & TBD & & & & & 1,623 & \\
\hline & Wilmington West Wind Energy Area & TBD & & & & & 627 & \\
\hline Ohio & Icebreaker & 2023 & & & 21 & & & 21 \\
\hline \multirow{2}{*}{ California } & Castle Wind & TBD & & & & & 1,000 & \multirow{2}{*}{1,150} \\
\hline & Redwood Coast & TBD & & & & & 150 & \\
\hline \multirow{4}{*}{ Hawaii } & Oahu North & TBD & & & & & 400 & \multirow{3}{*}{1,200} \\
\hline & Oahu South & TBD & & & & & 400 & \\
\hline & Progression & TBD & & & & & 400 & \\
\hline & & & 30 & 12 & 6,439 & 17,440 & 4,600 & 28,521 \\
\hline
\end{tabular}

Note: Projects listed by state where power will be delivered (for projects with known offtake pathways) 


\section{U.S. Offshore Wind Pipeline}

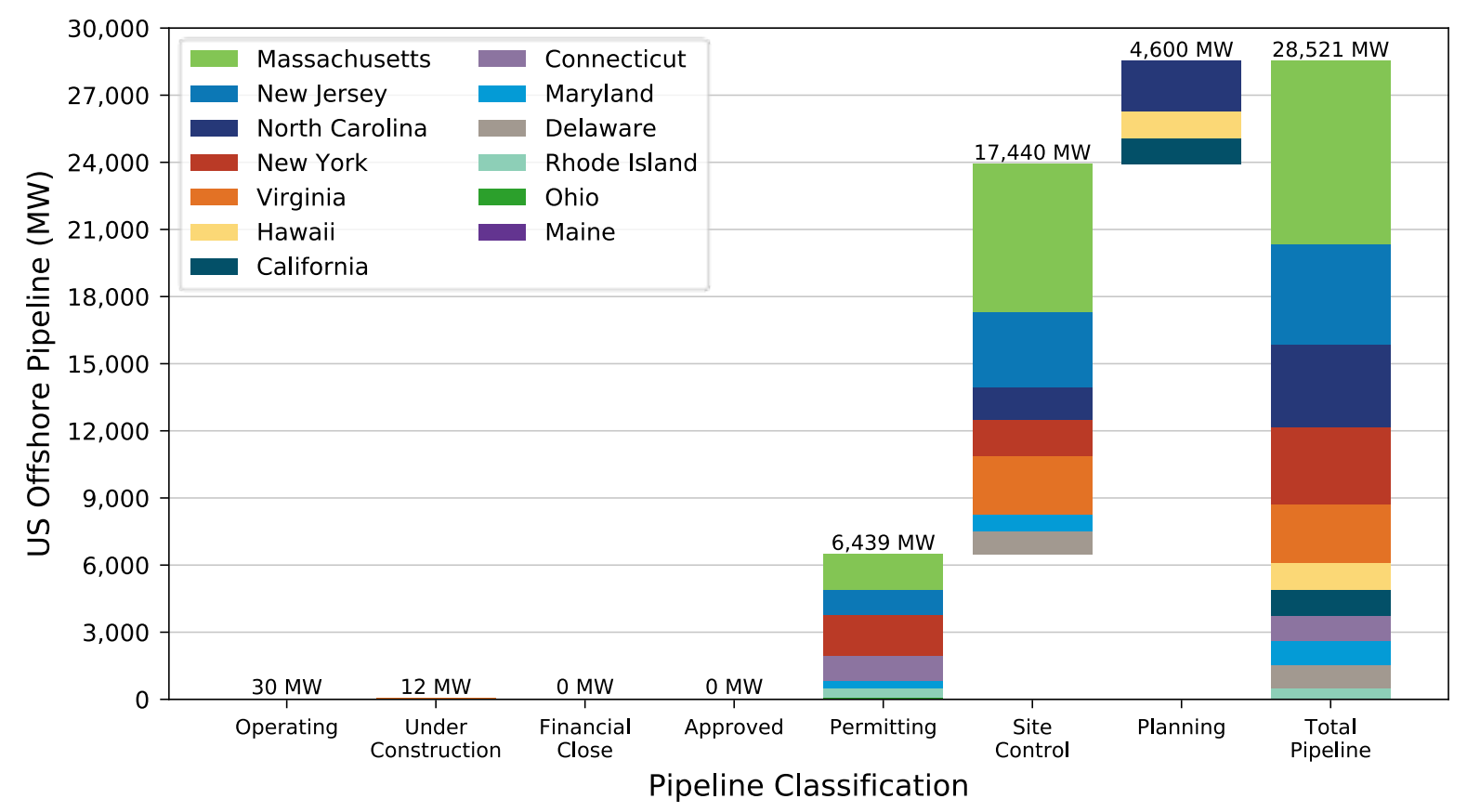

- The U.S. offshore wind pipeline grew by 2,697 MW in 2019 to a total capacity of $28,521 \mathrm{MW}$.

- The U.S. offshore wind pipeline is broken down as follows:

- $30 \mathrm{MW}$ is operating, which was unchanged in 2019

- $12 \mathrm{MW}$ is under construction

- 6,439 MW is in the permitting stage

- $17,440 \mathrm{MW}$ is under site control

- 4,600 MW is in planning. 


\section{U.S. Offshore Wind Pipeline by State}

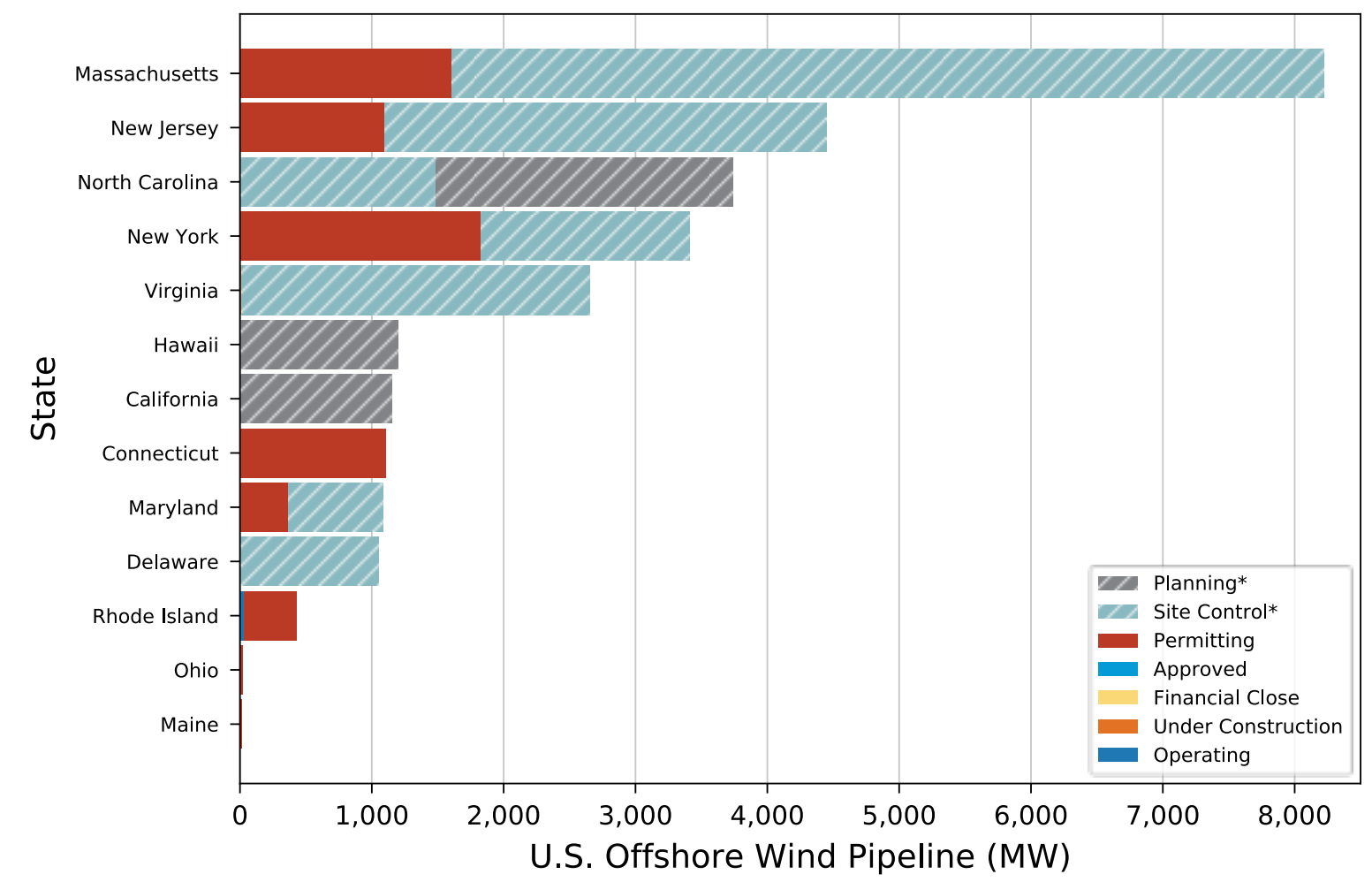

There are 11 coastal states participating in the U.S. pipeline:

- $\quad 30 \mathrm{MW}$ is operating in Rhode Island and $12 \mathrm{MW}$ is under construction in Virginia

- $\quad$ Red shading totals 6,439 MW, which represent projects that have advanced to the permitting stage

- Project capacity is assigned to the state receiving the power (red shading)

- Lease areas where power offtake is unspecified (hashed shading) are assigned to the state where the lease area is located, as identified by the Bureau of Ocean Energy Management ( BOEM). 


\section{Locations of U.S. Atlantic Coast Offshore Wind Pipeline Activity and Call Areas as of July 2020}

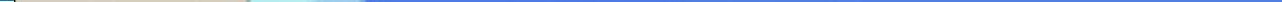


Atlantic Coast Offshore Wind Pipeline

\begin{tabular}{|c|c|c|c|c|c|c|c|c|c|c|c|}
\hline$\#$ & Location & Project Name & Status & COD & $\begin{array}{c}\text { Announced } \\
\text { Capacity (MW) }\end{array}$ & $\begin{array}{c}\text { Lease Area } \\
\text { Capacity (MW) }\end{array}$ & $\begin{array}{l}\text { Total Pipeline } \\
\text { Capacity (MW) }\end{array}$ & Lease Area & $\begin{array}{c}\text { Size } \\
\left(\mathbf{k m}^{2}\right)\end{array}$ & $\begin{array}{l}\text { Offtake } \\
\text { (MW) }\end{array}$ & Developers \\
\hline 1 & $\mathrm{ME}$ & New England Aqua Ventus I & Permitting & 2023 & 12 & 0 & 12 & State Lease & 9 & ME 12 & Aqua Ventus \\
\hline 2 & MA & Bay State Wind & Site Control & - & - & 2,277 & 2,277 & OCS-A 0500 & 759 & - & $\emptyset$ rsted/Eversource \\
\hline 3 & MA & Park City Wind & Permitting & 2025 & 804 & - & 804 & OCS-A 0501 & \multirow{2}{*}{676} & СТ 804 & Avangrid/CIP \\
\hline 4 & MA & Vineyard Wind + Residual & Permitting & 2023 & 800 & 421 & 1,221 & OCS-A 0501 & & MA 800 & Avangrid/CIP \\
\hline 5 & MA & Beacon Wind & Site Control & - & - & 1,564 & 1,564 & OCS-A 0520 & 521 & - & Equinor/BP \\
\hline 6 & MA & Mayflower Wind + Residual & Permitting & 2025 & 804 & 747 & 1,551 & OCS-A 0521 & 516 & MA 804 & EDPR/Shell \\
\hline 7 & MA & Liberty Wind & Site Control & - & - & 1,607 & 1,607 & OCS-A 0522 & 536 & - & Avangrid/CIP \\
\hline 8 & MA & Sunrise Wind & Permitting & 2024 & 880 & 0 & 880 & OCS-A 0487 & 272 & NY 880 & $\emptyset$ rsted/Eversource \\
\hline 9 & $\mathrm{RI}$ & Revolution Wind & Permitting & 2023 & 704 & 0 & 704 & OCS-A 0486 & \multirow{2}{*}{395} & RI 400/CT 304 & $\emptyset$ rsted/Eversource \\
\hline 10 & $\mathrm{RI}$ & South Fork & Permitting & 2023 & 130 & 0 & 130 & OCS-A 0517 & & NY 130 & $\emptyset$ rsted/Eversource \\
\hline 11 & $\mathrm{RI}$ & Block Island Wind Farm & Operating & 2016 & 30 & 0 & 30 & State Lease & 10 & $\mathrm{RI} 30$ & $\emptyset$ rsted/Eversource \\
\hline 12 & NY & Fairways North Call Area & Planning & - & - & - & - & - & - & - & - \\
\hline 13 & NY & Fairways South Call Area & Planning & - & - & - & - & - & - & - & - \\
\hline 14 & NY & Hudson North Call Area & Planning & - & - & - & - & - & - & - & - \\
\hline 15 & NY & Empire Wind & Permitting & 2024 & 816 & 1,584 & 2,400 & OCS-A 0512 & 321 & NY 816 & Equinor/BP \\
\hline 16 & NY & Hudson South Call Area & Planning & - & - & - & - & - & - & - & - \\
\hline 17 & NJ & Atlantic Shores Offshore Wind & Site Control & - & - & $2,500^{+}$ & 2,500 & OCS-A 0499 & 742 & - & EDF/Shell \\
\hline 18 & NJ & Ocean Wind + Residual & Permitting & 2024 & 1,100 & 847 & 1,947 & OCS-A 0498 & 649 & NJ 1,100 & $\varnothing$ rsted/PSEG \\
\hline 19 & $\mathrm{DE}$ & Garden State Offshore Energy & Site Control & - & - & 1,050 & 1,050 & OCS-A 0482 & 284 & - & $\varnothing$ rsted \\
\hline 20 & $\mathrm{DE}$ & Skipjack & Permitting & 2023 & 120 & 0 & 120 & OCS-A 0519 & 107 & MD 120 & $\varnothing$ rsted \\
\hline 21 & MD & MarWin + Residual & Permitting & 2023 & 248 & 718 & 966 & OCS-A 0490 & 322 & MD 248 & US Wind \\
\hline 22 & VA & Dominion & Site Control & - & - & 2,640 & 2,640 & OCS-A 0483 & 457 & - & Dominion \\
\hline 23 & VA & Coastal Virginia Offshore Wind & Under Construction & 2020 & 12 & 0 & 12 & OCS-A 0497 & 9 & VA 12 & Dominion/Ørsted \\
\hline 24 & NC & Kitty Hawk & Site Control & - & - & 1,485 & 1,485 & OCS-A 0508 & 495 & - & Avangrid \\
\hline 25 & NC & Wilmington West Call Area & Unleased & - & - & 627 & 627 & - & 209 & - & - \\
\hline 26 & NC & Wilmington East Call Area & Unleased & - & - & 1,623 & 1,623 & - & 541 & - & - \\
\hline 27 & SC & Grand Strand Call Area & Planning & - & - & - & - & - & - & - & - \\
\hline 28 & SC & Winyah Call Area & Planning & - & - & - & - & - & - & - & - \\
\hline 29 & SC & Cape Romain Call Area & Planning & - & - & - & - & - & - & - & - \\
\hline 30 & SC & Charleston Call Area & Planning & - & - & - & - & - & - & - & - \\
\hline \multirow[t]{2}{*}{31} & $\mathrm{OH}$ & Icebreaker & Permitting & 2023 & 21 & 0 & 21 & State Lease & 10 & $\mathrm{OH} 21$ & LEEDCo/Fred Olsen \\
\hline & & \multicolumn{2}{|c|}{ Atlantic Coast Total } & & 6,481 & 17,190 & 26,171 & & 7,840 & & \\
\hline
\end{tabular}




\section{Locations of U.S. West Coast Offshore Wind Pipeline
Activity and Call Areas as of July Coast Offshore Wind Pipeline
Activity and Call Areas as of July 2020}
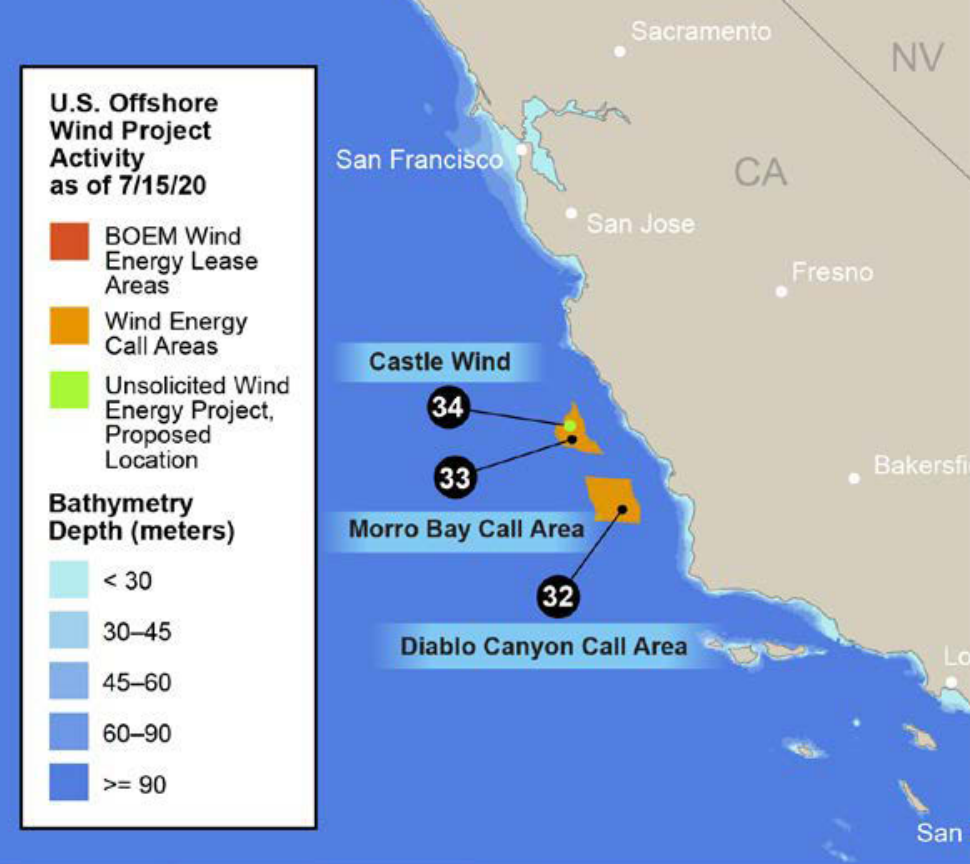
Locations of Hawaiian Offshore Wind Pipeline Activity and Call Areas as of July 2020

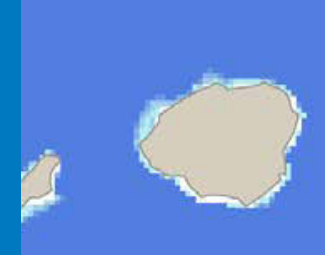

40
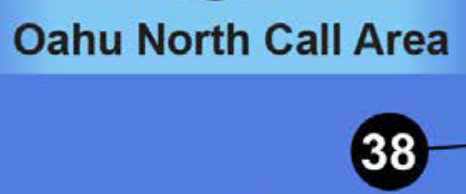

AWH Oahu

\section{AWH Oahu}

41

39 Progression



U.S. Offshore Wind
Project Activity as Project Activity as of $7 / 15 / 20$

BOEM Wind Energy Lease Areas

Wind Energy Call Areas

Unsolicited Wind Energy Project, Proposed Location

Bathymetry Depth (meters)

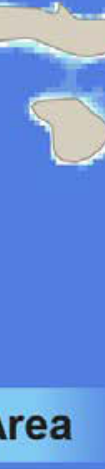

Note that the Hawaii call for nominations

supersedes the unsolicited requests in the Oahu

South Call Area and Oahu North Call Area.

Currently, these projects are not being processed by BOEM. 


\section{U.S. West Coast and Hawaiian Offshore Wind Pipeline}

\begin{tabular}{|c|c|c|c|c|c|c|c|c|c|c|c|}
\hline$\#$ & Location & Project Name & Planning Stage & $\begin{array}{c}\text { Commercial } \\
\text { Operations Date }\end{array}$ & $\begin{array}{c}\text { Announced } \\
\text { Capacity (MW) }\end{array}$ & $\begin{array}{c}\text { Lease Area } \\
\text { Capacity (MW) }\end{array}$ & $\begin{array}{l}\text { Total Pipeline } \\
\text { Capacity (MW) }\end{array}$ & Lease Area & Size $\left(\mathbf{k m}^{2}\right)$ & Offtake & Developers \\
\hline 32 & CA & Diablo Canyon Call Area & BOEM Call Area & - & - & - & - & - & - & - & - \\
\hline 33 & CA & Morro Bay Call Area & BOEM Call Area & - & - & - & - & - & - & - & - \\
\hline 34 & CA & Castle Wind & $\begin{array}{l}\text { Unsolicited Project } \\
\text { Application }\end{array}$ & - & 1,000 & - & 1,000 & - & 334 & - & Trident Winds/EnBW \\
\hline 35 & CA & Humboldt Call Area & BOEM Call Area & - & - & - & - & - & - & - & - \\
\hline 36 & CA & $\begin{array}{c}\text { Redwood Coast Energy } \\
\text { Authority }\end{array}$ & $\begin{array}{c}\text { Unsolicited Project } \\
\text { Application }\end{array}$ & - & 150 & - & 150 & - & 50 & - & EDPR/Aker/PPI \\
\hline 37 & $\mathrm{HI}$ & Oahu South Call Area & BOEM Call Area & - & - & - & - & - & - & - & AW Wind \\
\hline 38 & $\mathrm{HI}$ & AWH Oahu & $\begin{array}{c}\text { Unsolicited Project } \\
\text { Application }\end{array}$ & - & - & 400 & 400 & - & 133 & - & - \\
\hline 39 & $\mathrm{HI}$ & Progression & $\begin{array}{l}\text { Unsolicited Project } \\
\text { Application }\end{array}$ & - & - & 400 & 400 & - & 133 & - & Progression Wind \\
\hline 40 & $\mathrm{HI}$ & Oahu North Call Area & BOEM Call Area & - & - & - & - & - & - & - & - \\
\hline 41 & $\mathrm{HI}$ & AWH Oahu & $\begin{array}{l}\text { Unsolicited Project } \\
\text { Application }\end{array}$ & - & - & 400 & 400 & - & 133 & - & AW Wind \\
\hline & & \multicolumn{2}{|c|}{ West Coast \& Hawaii Total } & & 1,150 & 1,200 & 2,350 & & 783 & & \\
\hline
\end{tabular}




\section{U.S. Offshore Wind Market Estimates Through 2030}

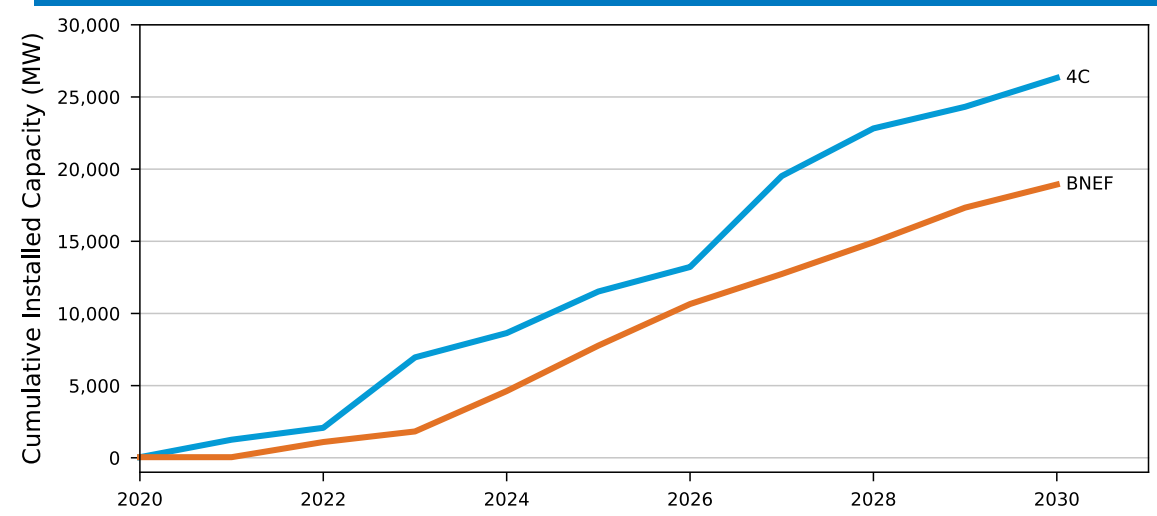

- $\quad 4 C$ Offshore predicts that cumulative U.S. offshore wind deployment will exceed 25,000 MW by 2030 (4C Offshore 2019).

- $\quad$ BNEF predicts cumulative U.S. offshore wind deployment will grow to nearly 19,000 MW by 2030 (BNEF 2019).



- $\quad$ These estimates are $50 \%$ to $70 \%$ higher than in their 2018 estimates when BNEF and 4C Offshore predicted 11,000 MW and 16,000 MW, respectively, by 2030. 


\section{U.S. State-Level Offshore Wind Procurements}

\begin{tabular}{|c|c|c|c|c|c|c|c|}
\hline State & $\begin{array}{l}\text { Capacity } \\
\text { Commitment } \\
\text { (MW) }\end{array}$ & $\begin{array}{l}\text { Target } \\
\text { Year }\end{array}$ & $\begin{array}{l}\text { Amount } \\
\text { Solicited } \\
\text { (MW) }\end{array}$ & Contract Type & $\begin{array}{c}\text { Year } \\
\text { Enacted }\end{array}$ & Authority & $\begin{array}{l}\text { Renewables } \\
\text { Portfolio } \\
\text { Standards } \\
\text { (RPS) Goal }\end{array}$ \\
\hline MA & 3,200 & 2035 & 1,604 & PPA & $\begin{array}{l}2016 \\
2018\end{array}$ & $\begin{array}{l}\text { An Act to Promote Energy Diversity } \\
\text { An Act to Advance Clean Energy }\end{array}$ & $35 \%$ by 2030 \\
\hline RI & 430 & - & 430 & PPA & & - & $31 \%$ by 2030 \\
\hline NJ & 7,500 & 2035 & $3,500^{A}$ & OREC & $\begin{array}{l}2010 \\
2018 \\
2019\end{array}$ & $\begin{array}{c}\text { Offshore Wind Economic Development Act } \\
\text { E.O. 8/Assembly Bill } 3723 \\
\text { E.0. } 92\end{array}$ & $50 \%$ by 2030 \\
\hline MD & 1,568 & 2030 & 368 & OREC & $\begin{array}{l}2013 \\
2019\end{array}$ & $\begin{array}{l}\text { Maryland Offshore Wind Energy Act } \\
\text { Senate Bill } 516\end{array}$ & $50 \%$ by 2030 \\
\hline NY & 9,000 & 2035 & $4,326^{\text {B }}$ & OREC & $\begin{array}{l}2018 \\
2019\end{array}$ & $\begin{array}{c}\text { Case } 18 \text {-E0071 } \\
\text { Climate Leadership \& Community } \\
\text { Protection Act }\end{array}$ & $70 \%$ by 2030 \\
\hline CT & 2,000 & 2030 & 1,104 & PPA & $\begin{array}{l}2017 \\
2019\end{array}$ & $\begin{array}{l}\text { Public Act } 17-144 \\
\text { House Bill } 7156\end{array}$ & $44 \%$ by 2030 \\
\hline VA & 5,200 & 2034 & 12 & Utility Owned & 2020 & Virginia Clean Economy Act & $100 \%$ by 2050 \\
\hline Total & 28,898 & & 11,380 & & & & \\
\hline
\end{tabular}

A - In July 2020, New Jersey announced its second offshore wind solicitation for between 1,200 MW and 2,400 MW. Awards are expected in June 2021.

- Five states implemented new procurement commitments in 2019 and early 2020 (see green text).

- State procurement commitments grew from $19,968 \mathrm{MW}$ in 2018 to $28,898 \mathrm{MW}$ in early 2020, corresponding to 8,930 MW of new commitments.

- State procurement goals of $28,898 \mathrm{MW}$ are now larger than the U.S. pipeline of $28,521 \mathrm{MW}$.

B - In July 2020, New York announced its next offshore wind solicitation for between $1,500 \mathrm{MW}$ and 2,500 MW. Awards are expected in the fourth quarter of 2020. Power purchase agreement (PPA) 


\section{Timeline of U.S. Offshore Wind Procurements by State}

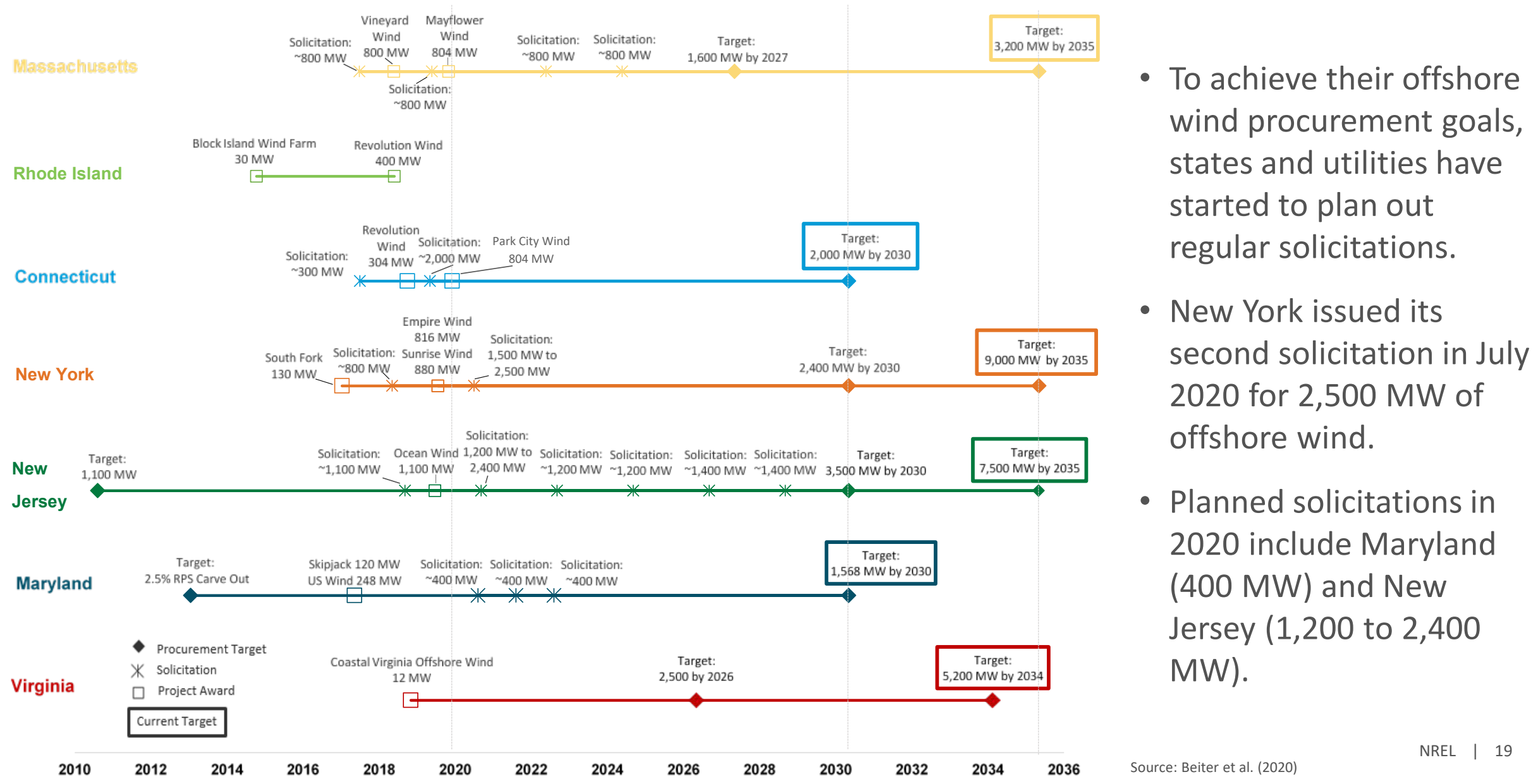




\section{U.S. Offshore Wind Project Offtake Agreements}

\begin{tabular}{|c|c|c|c|c|c|c|c|c|c|}
\hline Project & $\begin{array}{l}\text { Year } \\
\text { Signed }\end{array}$ & $\begin{array}{l}\text { Size } \\
\text { (MW) }\end{array}$ & $\begin{array}{c}\text { Duration } \\
\text { (years) }\end{array}$ & $\begin{array}{l}\text { Offtake } \\
\text { State }\end{array}$ & $\begin{array}{c}\text { Offtake } \\
\text { Mechanism }\end{array}$ & $\begin{array}{l}\text { Regulator } \\
\text { Approved }\end{array}$ & $\begin{array}{l}\text { Levelized Price } \\
\text { \$/Megawatt-hour } \\
\text { (MWh) }\end{array}$ & $\begin{array}{l}\text { Power } \\
\text { Delivery }\end{array}$ & $\begin{array}{l}\text { Power } \\
\text { Purchaser }\end{array}$ \\
\hline $\begin{array}{l}\text { Block Island } \\
\text { Wind Farm }\end{array}$ & 2010 & 30 & 20 & $\mathrm{RI}$ & PPA & Yes & 244 & 2016 & National Grid \\
\hline South Fork & 2017 & 130 & 20 & NY & PPA & Yes & 163 & 2023 & Long Island Power Authority (LIPA) \\
\hline US Wind & 2017 & 248 & 20 & MD & MD OREC & Yes & 131.94 & 2023 & PJM \\
\hline Skipjack & 2017 & 120 & 20 & MD & MD OREC & Yes & 131.94 & 2023 & PJM \\
\hline Vineyard Wind & 2018 & 400 & 20 & MA & PPA & Yes & 74 & 2023 & National Grid, Eversource, Unitil \\
\hline Vineyard Wind & 2018 & 400 & 20 & MA & PPA & Yes & 65 & 2024 & National Grid, Eversource, Unitil \\
\hline $\begin{array}{l}\text { Coastal Virginia } \\
\text { Offshore Wind }\end{array}$ & 2018 & 12 & 20 & VA & Utility Owned & Yes & 780 & 2020 & Dominion Energy* \\
\hline Revolution Wind & 2018 & 200 & 20 & CT & PPA & Yes & 99.50 & 2023 & Eversource \& UIL \\
\hline Revolution Wind & 2018 & 104 & 20 & CT & PPA & Yes & 98.43 & 2023 & Eversource \& UIL \\
\hline Revolution Wind & 2019 & 400 & 20 & $\mathbf{R I}$ & PPA & Yes & 98.43 & 2023 & National Grid \\
\hline Ocean Wind & 2019 & 1,100 & 20 & NJ & NJ OREC & Yes & 116.82 & 2024 & PJM \\
\hline Empire Wind & 2019 & 816 & 25 & NY & NY OREC & Yes & 83.36 & 2024 & $\begin{array}{c}\text { New York Independent System } \\
\text { Operator (NYISO) }\end{array}$ \\
\hline Sunrise Wind & 2019 & 880 & 25 & NY & NY OREC & Yes & 83.36 & 2024 & NYISO \\
\hline Aqua Ventus & 2019 & 12 & 20 & ME & PPA & Yes & Undisclosed & TBD & Central Maine Power \\
\hline Mayflower Wind & 2020 & 400 & 20 & MA & PPA & Yes & 58.47 & 2025 & National Grid, Eversource, Until \\
\hline Mayflower Wind & 2020 & 404 & 20 & MA & PPA & Yes & 58.47 & 2025 & National Grid, Eversource, Until \\
\hline Park City Wind & & 804 & 20 & CT & PPA & Pending & $\mathrm{N} / \mathrm{A}$ & 2025 & Eversource \& UIL \\
\hline Icebreaker & & 21 & TBD & $\mathrm{OH}$ & PPA & Pending & $\mathrm{N} / \mathrm{A}$ & TBD & TBD \\
\hline
\end{tabular}

Source: Beiter et al. (2020)

Note: Offtake agreements signed in 2019 and 2020 are in green text






\section{U.S. State Port and Infrastructure Investments Near \$2 Billion}

\begin{tabular}{|c|c|c|c|c|c|}
\hline State & Location & $\begin{array}{l}\text { Announced } \\
\text { Date }\end{array}$ & Amount & Investor(s) & Description \\
\hline \multirow{2}{*}{ Massachusetts } & $\begin{array}{l}\text { New Bedford } \\
\text { Marine Commerce } \\
\text { Terminal }\end{array}$ & $2 / 10 / 2020$ & N/A & $\begin{array}{l}\text { Avangrid/CIP } \\
\text { EDPR/Shell }\end{array}$ & $\begin{array}{l}\text { Vineyard Wind signed an 18-month lease starting in December 2020. They also signed a } \\
\text { subsequent lease to use the terminal for the Mayflower Wind project, which is expected to } \\
\text { start construction in } 2024 \text {. }\end{array}$ \\
\hline & Brayton Point & $5 / 13 / 2019$ & $\begin{array}{l}\$ 650 \\
\text { million }\end{array}$ & Anbaric Partners & $\begin{array}{l}\text { Develop premier offshore wind development center. Investments include a 1,200-MW HVDC } \\
\text { converter, a } 400-\mathrm{MW} \text { battery, additional laydown space, and a maintenance dock. }\end{array}$ \\
\hline \multirow[b]{2}{*}{ Rhode Island } & Port of Providence & $6 / 3 / 2019$ & N/A & $\emptyset$ rsted \& Eversource & Support the construction of the Revolution Wind projects. \\
\hline & Quonset Point & & N/A & $\varnothing$ rsted \& Eversource & $\begin{array}{l}\text { Support the construction of the Revolution Wind projects. Pier } 2 \text { is being upgraded to support } \\
\text { offshore wind activities. }\end{array}$ \\
\hline \multirow[b]{2}{*}{ New Jersey } & Port of Paulsboro & $6 / 3 / 2019$ & N/A & $\varnothing$ rsted & $\begin{array}{l}\text { Signed a memorandum of understanding with EEW, a German steel manufacturer, to } \\
\text { construct a monopile manufacturing facility to support Ocean Wind project and other projects } \\
\text { in the U.S. pipeline. }\end{array}$ \\
\hline & $\begin{array}{l}\text { New Jersey Wind } \\
\text { Port }\end{array}$ & $6 / 16 / 2020$ & $\begin{array}{l}\$ 300-\$ 400 \\
\text { million }\end{array}$ & $\begin{array}{l}\text { NJ Economic } \\
\text { Development } \\
\text { Authority }\end{array}$ & $\begin{array}{l}\text { Develop port in Lower Alloways Creek Township to support offshore wind construction and } \\
\text { operations. Initial phase to include } 30 \text { acres for marshalling and } 25 \text { acres for component } \\
\text { manufacturing, with construction to begin in } 2021 \text {. Second phase to add } 150 \text { acres for } \\
\text { marshalling and manufacturing. }\end{array}$ \\
\hline Maryland & Tradepoint Atlantic & $7 / 23 / 2019$ & $\begin{array}{l}\$ 13.2 \\
\text { million }\end{array}$ & $\varnothing$ rsted & $\begin{array}{l}\text { Strengthen ground-bearing capacity at the port to allow heavy-lift cranes and specialized } \\
\text { transporters to move wind turbine components, some weighing as much as } 2,000 \text { tons, from } \\
\text { ships onto the site. Will support the Skipjack project. }\end{array}$ \\
\hline \multirow{2}{*}{ New York } & Port of Coeymans & $11 / 14 / 2019$ & $\begin{array}{l}\$ 287 \\
\text { million }\end{array}$ & New York State & $\begin{array}{l}\text { Increase laydown space and prepare the port to support construction and staging needs for } \\
\text { the Empire Wind project. Partnered with heavy-lift specialists Mammoet to invest in a new } \\
\text { heavy-lift crane and other specialty equipment. }\end{array}$ \\
\hline & New York ports & $7 / 21 / 2020$ & $\begin{array}{l}\$ 400 \\
\text { million }\end{array}$ & New York State & $\begin{array}{l}\text { Request for proposals for investment in port infrastructure. Priorities are offshore wind } \\
\text { staging and/or manufacturing and related uses. Up to } \$ 200 \text { million from New York state, } \\
\text { matched } 1: 1 \text { by private investment. }\end{array}$ \\
\hline \multirow[t]{2}{*}{ Connecticut } & $\begin{array}{l}\text { New London State } \\
\text { Pier }\end{array}$ & $2 / 12 / 2020$ & $\begin{array}{l}\$ 157 \\
\text { million }\end{array}$ & $\emptyset$ rsted \& Eversource & $\begin{array}{l}\text { Increase laydown space, the number and size of vessel berths, and the ability to lift and store } \\
\text { heavy cargo. The redevelopment is expected to be complete by } 2022 \text {. The pier will be used for } \\
\text { turbine preassembly and project staging for Revolution Wind, South Fork, and Sunrise Wind } \\
\text { projects. }\end{array}$ \\
\hline & Bridgeport & 11/11/2019 & N/A & Avangrid & $\begin{array}{l}\text { Redevelop a currently underutilized } 18.3 \text {-acre waterfront to do critical foundation transition } \\
\text { piece steel fabrication and final outfitting. Port will also serve as an operation and } \\
\text { maintenance hub for the Park City Wind project. }\end{array}$ \\
\hline Virginia & $\begin{array}{l}\text { Portsmouth Marine } \\
\text { Terminal }\end{array}$ & $1 / 28 / 2020$ & $\$ 33$ million & $\emptyset$ rsted & $\begin{array}{l}\text { Signed a lease for the construction of the Coastal Virginia Offshore Wind Project. Will also } \\
\text { install cranes and other specialty improvements. }\end{array}$ \\
\hline
\end{tabular}




\section{U.S. Offshore Wind Grid Interconnection Queues}

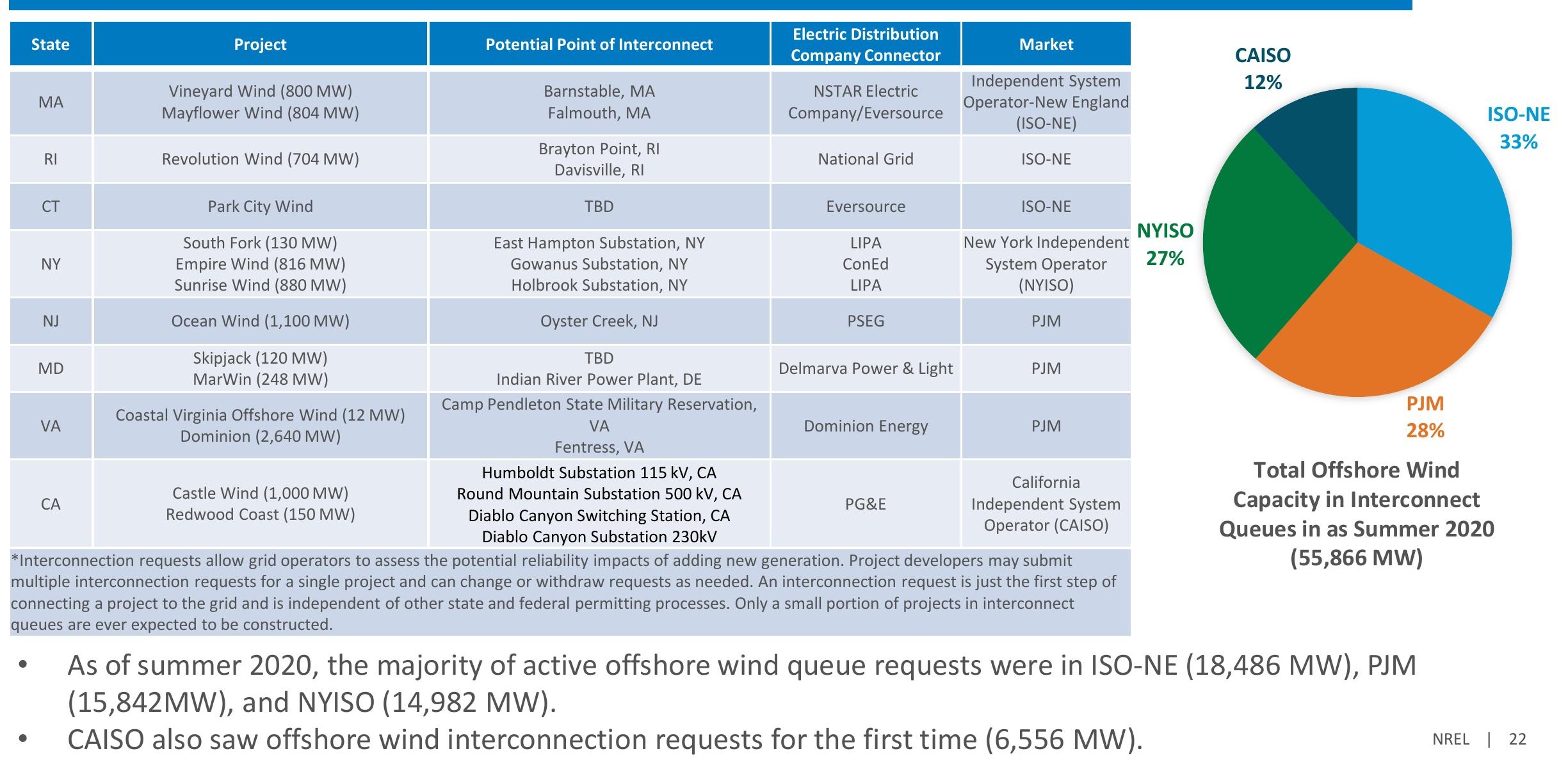




\section{Other Related U.S. Developments}

- In August 2019, BOEM announced that it would prepare a supplement to the draft Environmental Impact Statement for the Vineyard Wind project. The supplement was published in June 2020 and assessed effects from an expanded cumulative impacts scenario, previously unavailable fishing data, a new transit lane alternative, and changes to the project since the publication of the first draft Environmental Impact Statement.

- The U.S. Coast Guard published a report on May 14, 2020, with recommendations for turbine spacing to accommodate transit lanes, fishing, and search and rescue operations.

- $\quad$ The 12-MW Coastal Virginia Offshore Wind (CVOW) project is under construction and is the first project in U.S. federal waters. Installation of the two 6-MW turbines was completed in June 2020, with grid interconnect scheduled for fall 2020.

- Dominion Energy announced plans to develop a 2,640-MW offshore wind project in its Virginia lease area, with an estimated COD of 2026, based on experience gained from CVOW. Siemens Gamesa has conditionally agreed to supply 14-MW SG 14-222 direct-drive turbines for the project.

- $\quad$ GE announced that it will supply its 12-MW Haliade-X turbines to Ørsted for two projects: Skipjack, a 120-MW project off the coast of Maryland that is expected to be commissioned in 2022, and Ocean Wind, a 1,100-MW project off the coast of New Jersey, with a COD of 2024. 


\section{Other Related U.S. Developments (continued)}

- In 2019, Maine's public utility commission approved an updated PPA for University of Maine's 12-MW Aqua Ventus floating demonstration project.

- In August 2020, the University of Maine announced a joint venture called New England Aqua Ventus, LLC, with Mitsubishi subsidiary Diamond Offshore Wind, and RWE Renewables, to develop the project, which is now positioned to be the first U.S. floating wind project using commercial technology.

- $\quad$ The Ohio Power Siting Board gave LEEDCo conditional approval to move forward with its 21MW project in Lake Erie. The DOE-supported demonstration project is still in the process of finalizing its offtake agreements and other technical considerations before beginning construction.

- A consortium led by Dominion Energy is developing a Jones-Act-compliant turbine installation vessel (TIV). With a projected entry into service of 2023, it would be the first U.S.-flagged TIV. 


\section{Summary - U.S. Offshore Wind Data}

- The U.S. offshore wind pipeline grew from 25,824 MW in 2018 to 28,521 MW by the end of 2019 , due primarily to developers announcing additional project capacity within existing lease areas.

- In March 2020, the amount of offshore wind capacity under federal and state permitting with a signed offtake agreement was 6,439 MW. This was more than triple the 2,043-MW capacity reported in March 2019, indicating significant U.S. industry development over the past year.

- The Internal Revenue Service (IRS) modified its safe harbor guidance to allow projects under construction an additional year to be placed in service to mitigate effects of potential COVID19-related delays for projects utilizing renewable energy tax credits.

- In 2019, a total of nearly \$2 billion of investments were proposed for new offshore wind port and infrastructure upgrades. 
Global Offshore Wind Data 
\begin{tabular}{|llll}
\hline United Kingdom & China & Belgium & Other Europe \\
Germany & Denmark & Netherlands & Other Asia
\end{tabular}
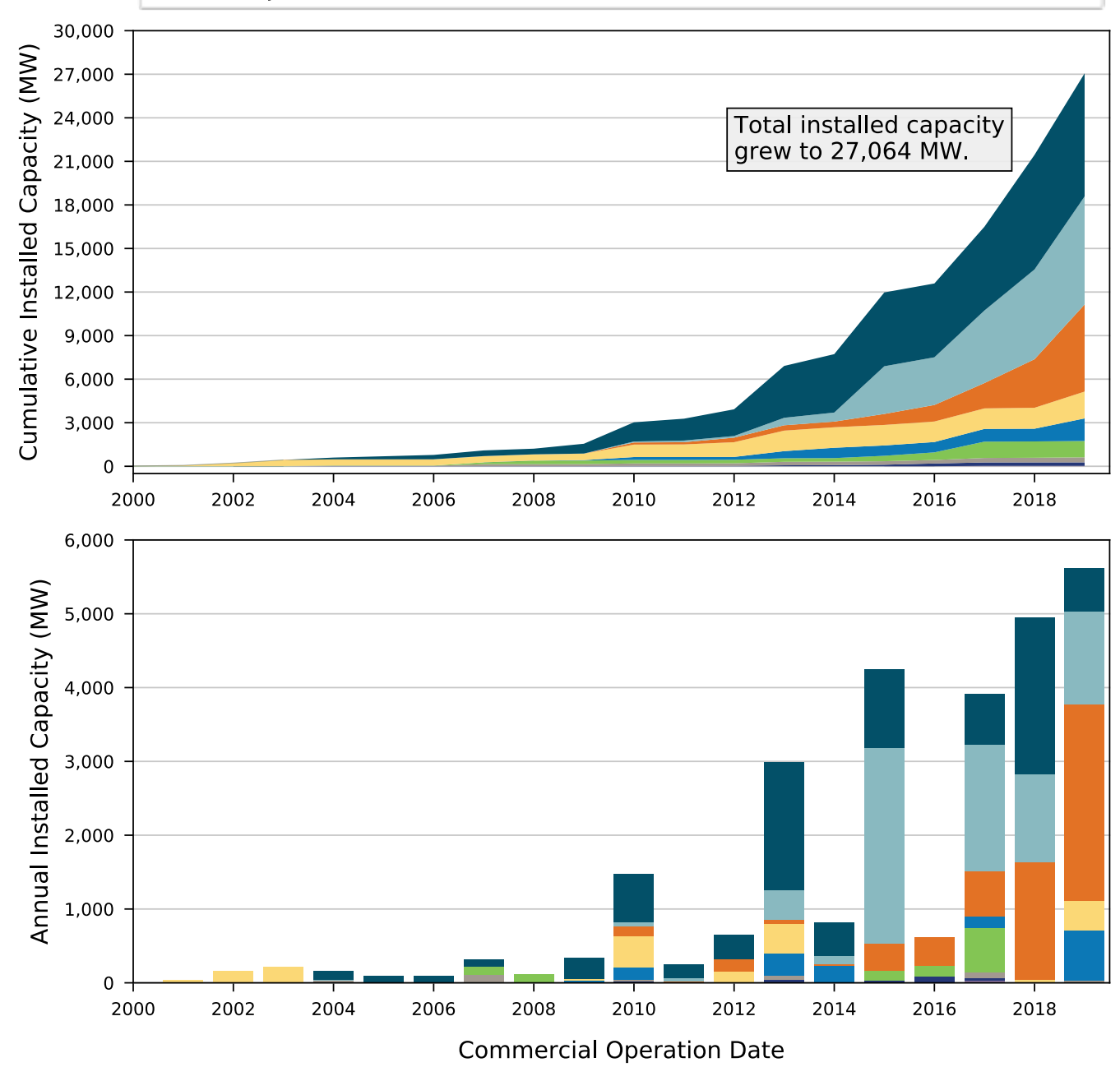

\section{Global Offshore Wind in 2019}

- $\quad$ Cumulative installed offshore wind capacity grew to 27,064 MW in 2019.

- New capacity additions reached a record high of 5,618 $\mathrm{MW}$ installed in 2019 and early 2020. 

in 2019

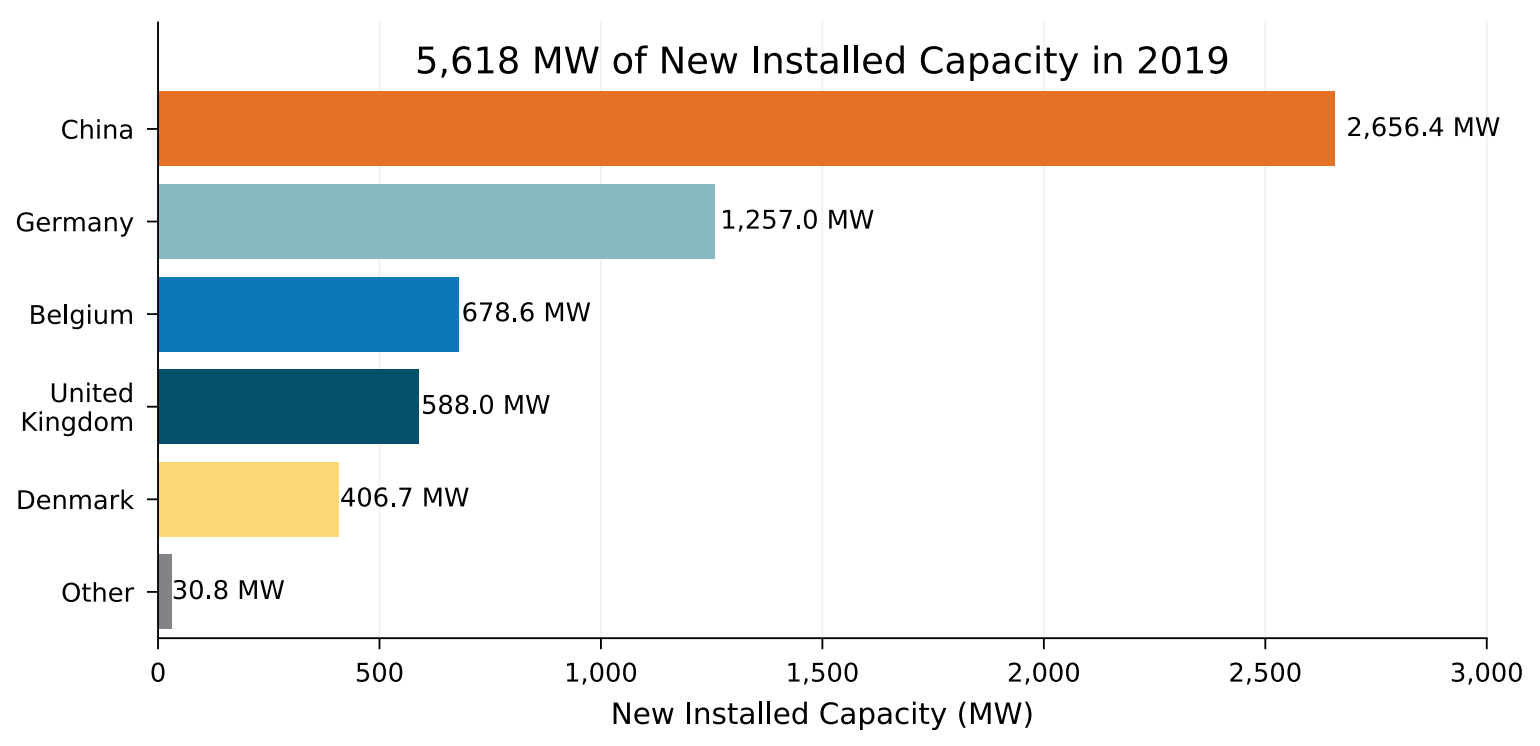

- $\quad$ Five countries contributed $99 \%$ of all new installations in 2019.

- China installed the most capacity, with $47 \%$ of the new additions.

- Germany installed 1,257 MW in 2019 , or about $22 \%$ of new additions.

- Belgium, the United Kingdom (UK), and Denmark installed the remaining major share of offshore wind in 2019. 


\section{Total Global Offshore Wind Pipeline}

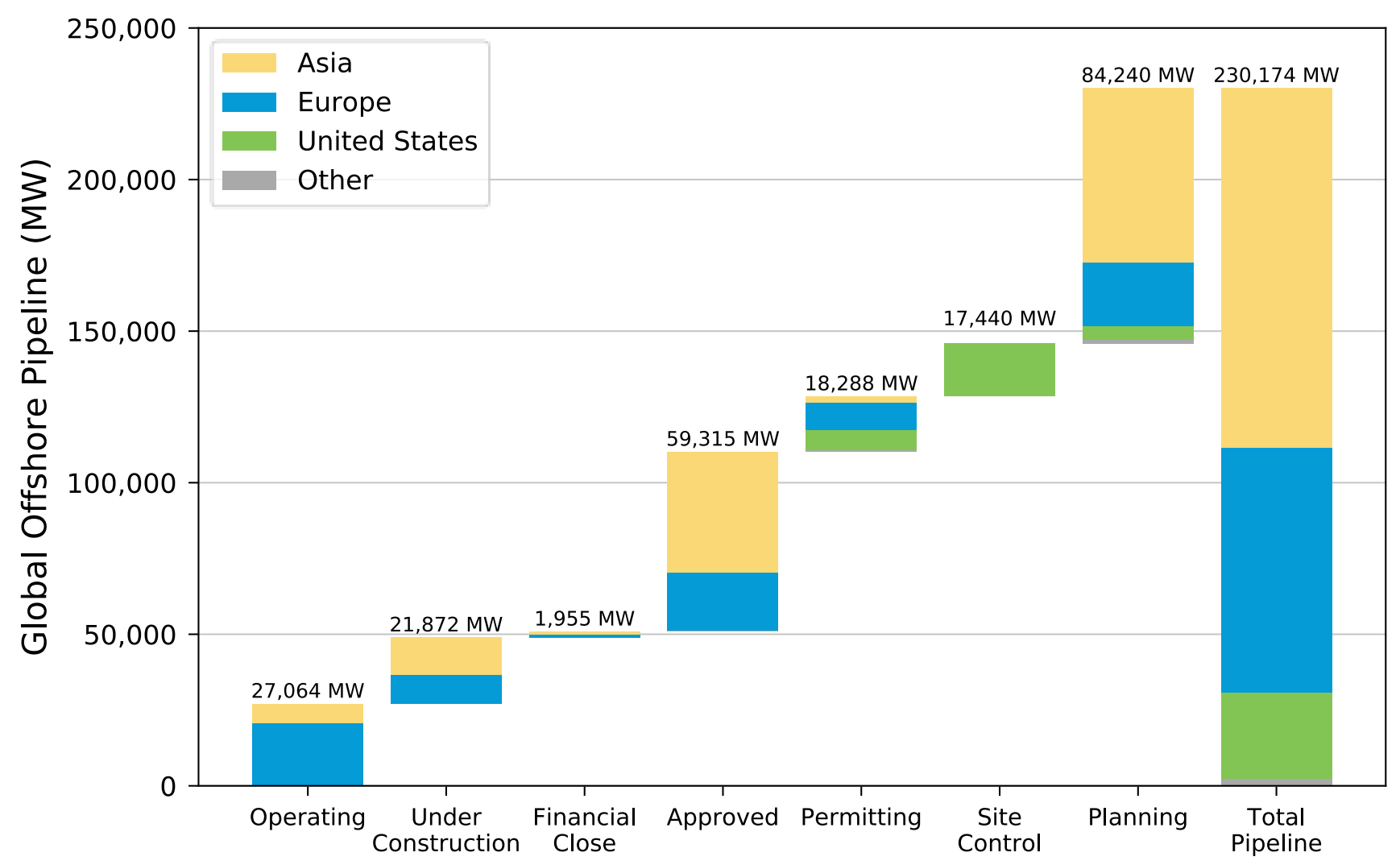

- The current global pipeline of offshore wind is 230,174 $\mathrm{MW}$, including:

- 27,064 MW operating

- 81,872 MW approved through respective national regulatory processes, reached financial close, or under construction.

- 203,110 MW of announced capacity.

- Most of these projects are in Europe and Asia.

- The pipeline encompasses projects completed (or reported) between 1990 and 2038. 

in 2019

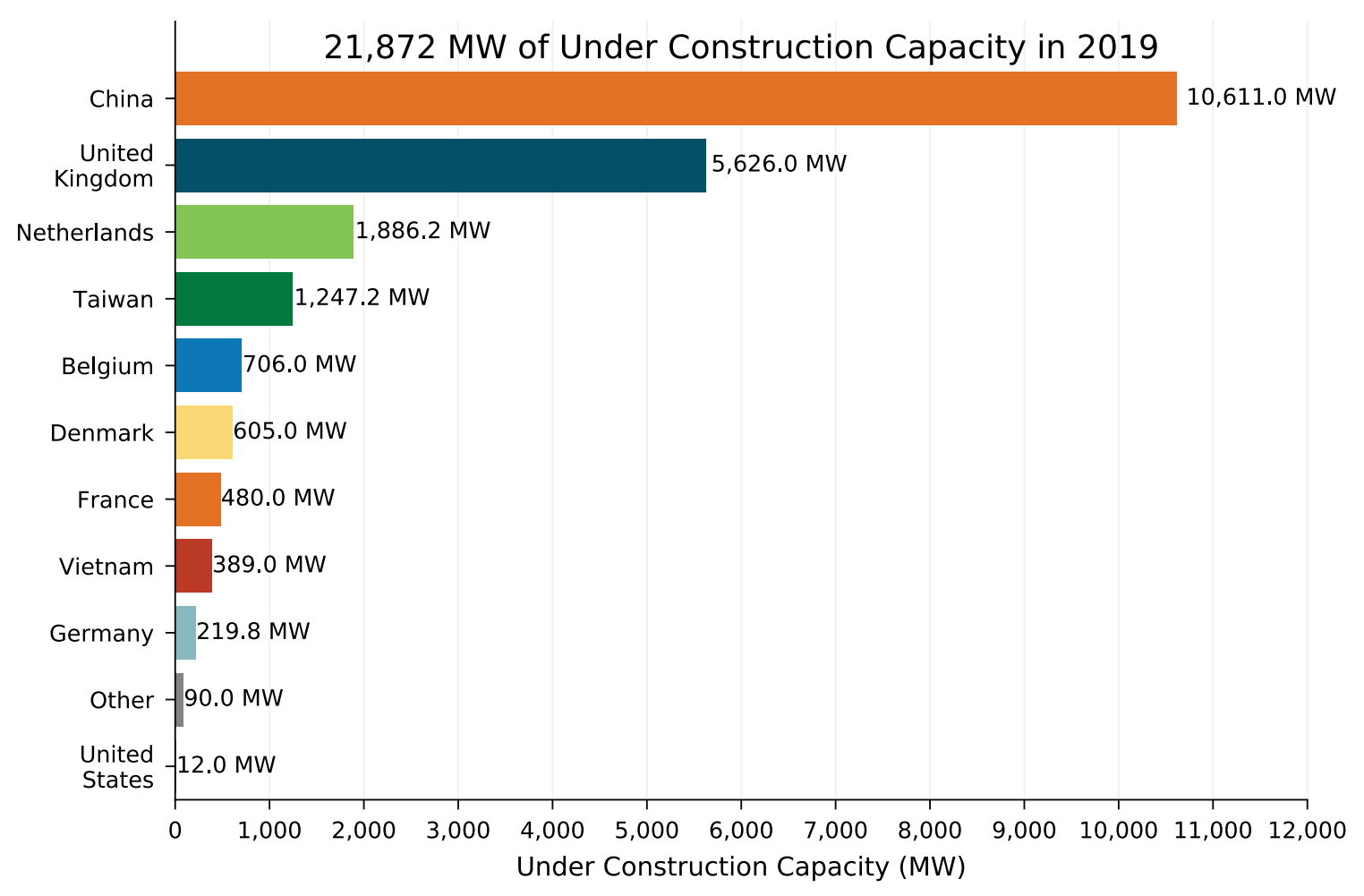

- Globally, 21,872 MW of offshore wind was reported to be under construction at the end of 2019.

- $10,611 \mathrm{MW}$ of projects under construction indicate that China has the potential to lead in new capacity over the next few years.

- The UK has 5,626 MW under construction.

- The 12-MW Coastal Virginia Offshore Wind project is under construction in the United States and will be the second project in operation. 


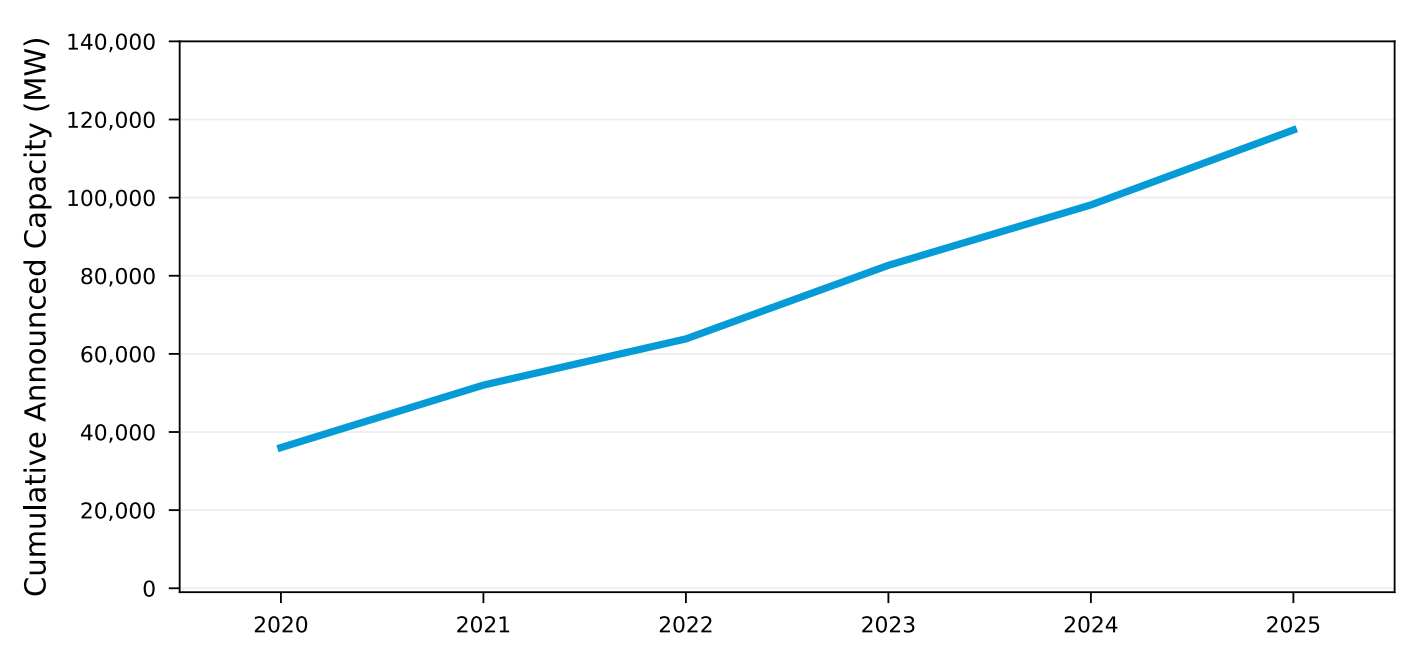

\section{Offshore Wind Projects} with Announced COD

- Global offshore wind pipeline data show nearly $120,000 \mathrm{MW}$ with announced COD by 2025

- Capacity expected to be installed annually (based on announced COD) grows from over $8,800 \mathrm{MW}$ in 2020 to over 19,000 MW in 2025

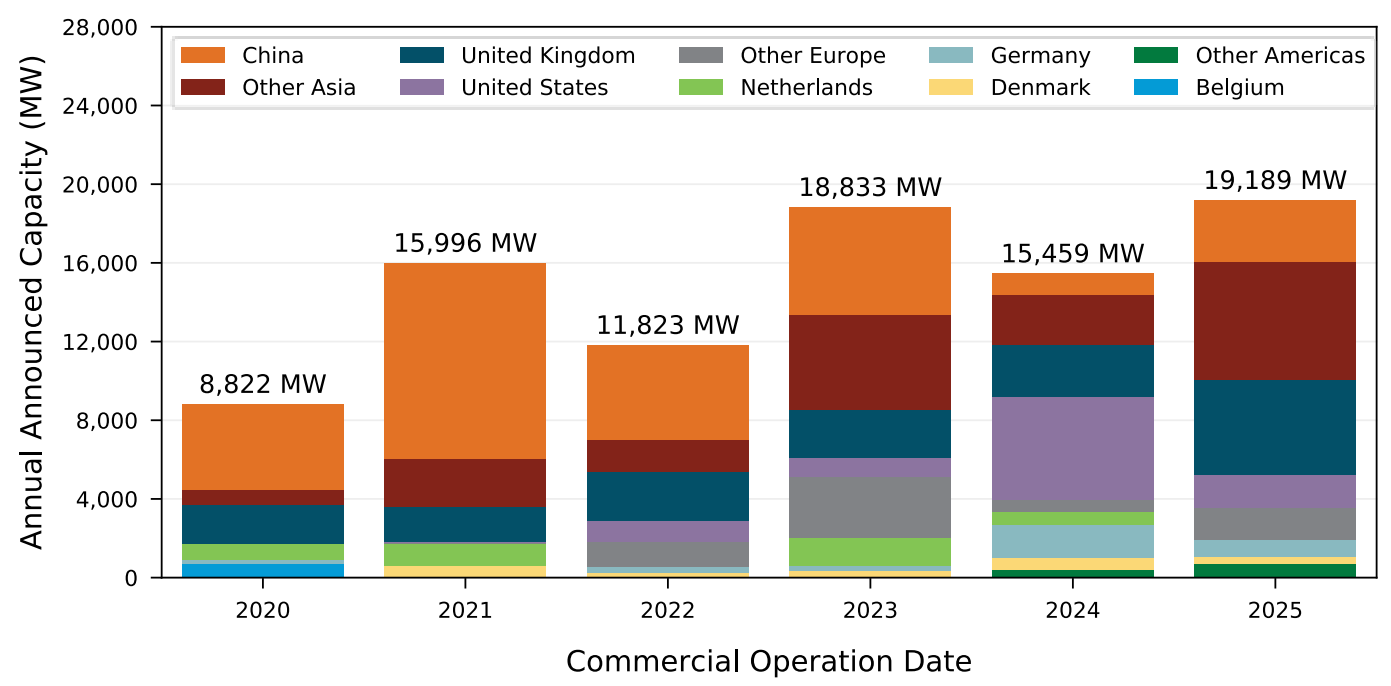




\section{Estimated Cumulative Offshore Wind Capacity Based on Developer-Announced COD Through 2025}



Beyond 2025, most projects have not yet announced a COD. 


\section{Cumulative Offshore Wind Capacity by Country Based on Developer-Announced COD Through 2025}

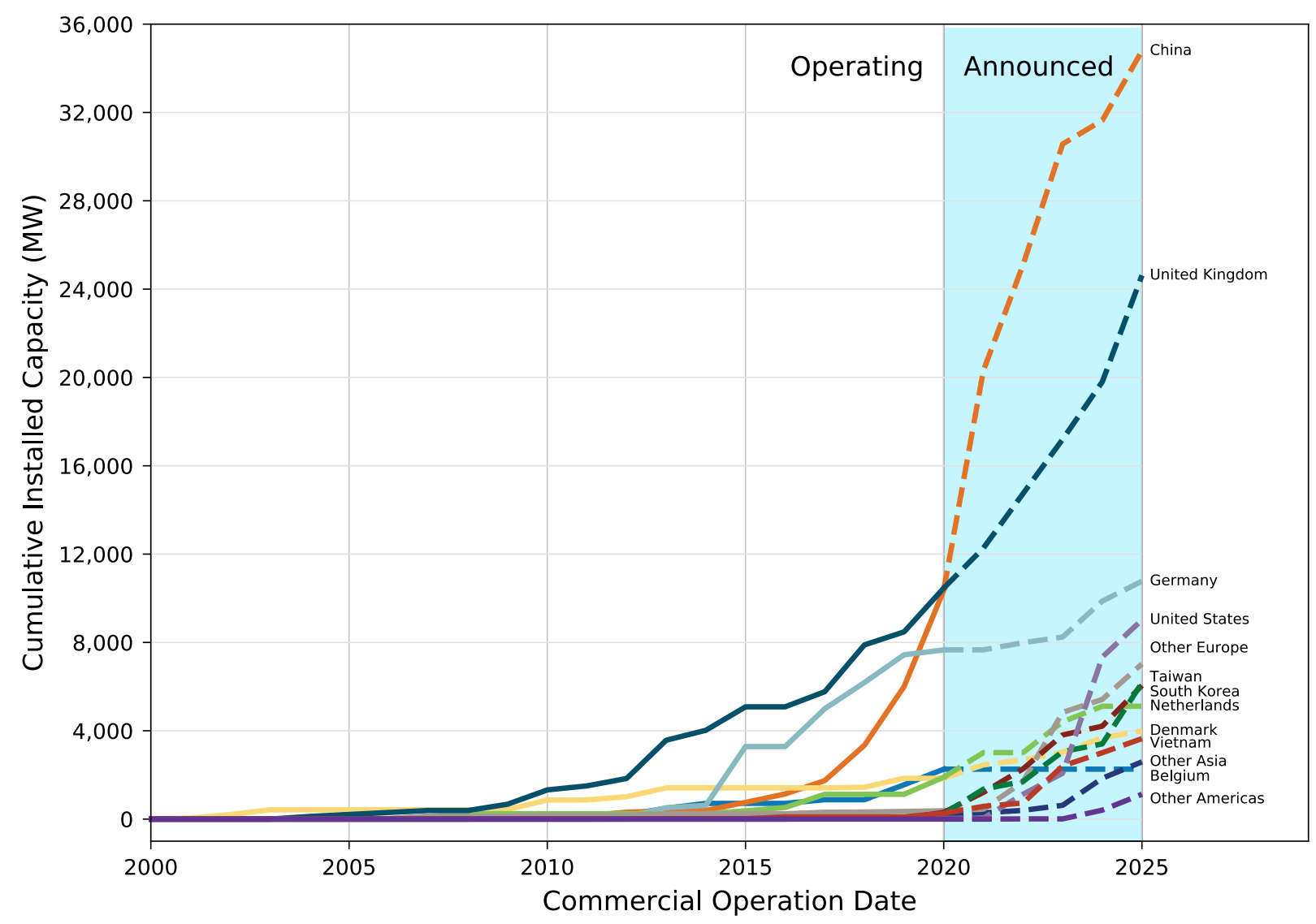

- Developer-announced CODs show greatest installed capacity in China and the UK through 2025

- Announced U.S. projects increase significantly from 2023 to 2025

- Capacity by announced CODs grows significantly in other Asian markets (e.g., South Korea, Taiwan, Vietnam) through 2025. 


\section{Global Offshore Wind Estimates Through 2030}

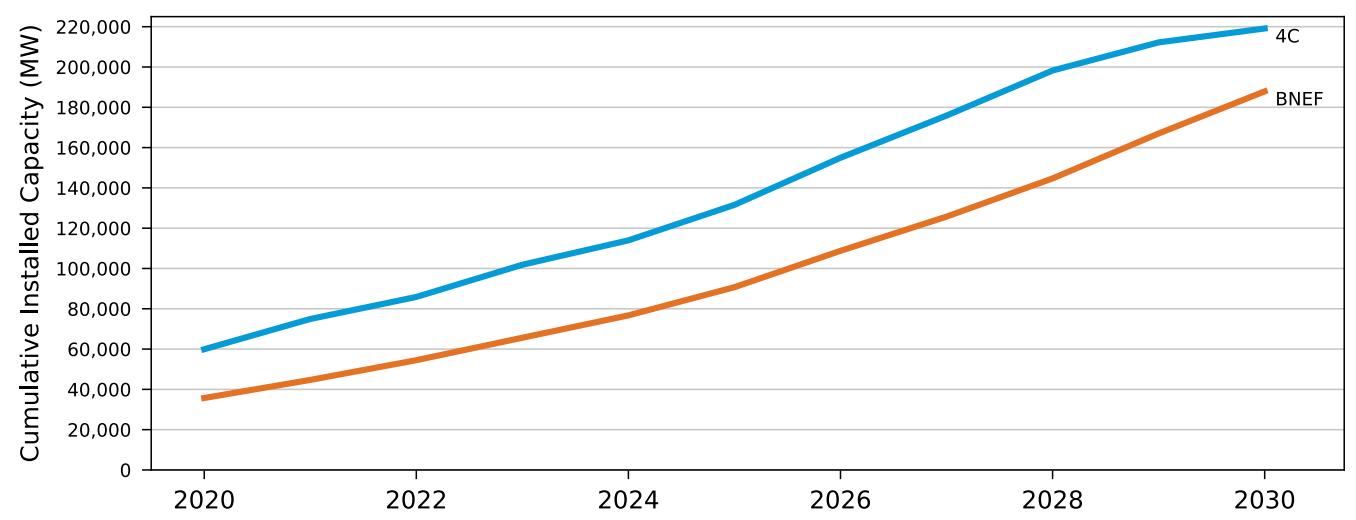

- In 2019, 4C Offshore estimates that cumulative global offshore wind deployment will grow to nearly 220,000 MW by 2030 (4C Offshore 2019).

- In 2019, BNEF estimates cumulative global offshore wind deployment will grow to nearly 188,000 MW by 2030 (BNEF 2019).
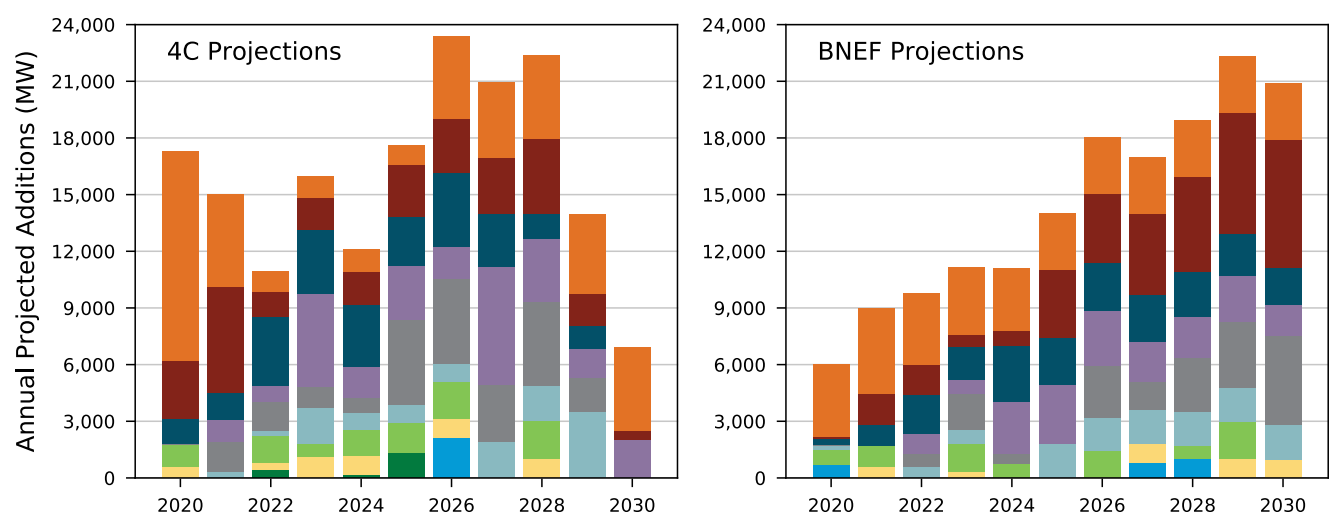

Commercial Operation Date

$\begin{array}{lll}\text { China } & \text { United Kingdom } & \text { Other Europe } \\ \text { Other Asia } & \text { United States } & \text { Netherlands } \\ \text { Germany } & \text { Denmark }\end{array}$

- For comparison, these 2030 estimates in 2018 were 154 gigawatts from BNEF and 193 gigawatts from $4 \mathrm{C}$ Offshore. 


\section{Summary - Global Offshore Wind Data}

- In 2019, global installed offshore wind capacity grew by $19 \%$ from the previous year, reaching 27,064 MW. Europe and Asia were the most active markets, adding a combined total of 5,618 MW in new capacity.

- In 2019, 22 new offshore wind projects commenced operations globally: 12 in China, 4 in Germany, 2 in Belgium, and 1 each in Denmark, Japan, Norway, and the UK.

- In 2019, for the first time, China had the largest annual capacity addition of any country, with 2,656 MW added. 
Global Floating Offshore Wind Data 


\section{Global Floating Offshore Wind Pipeline}

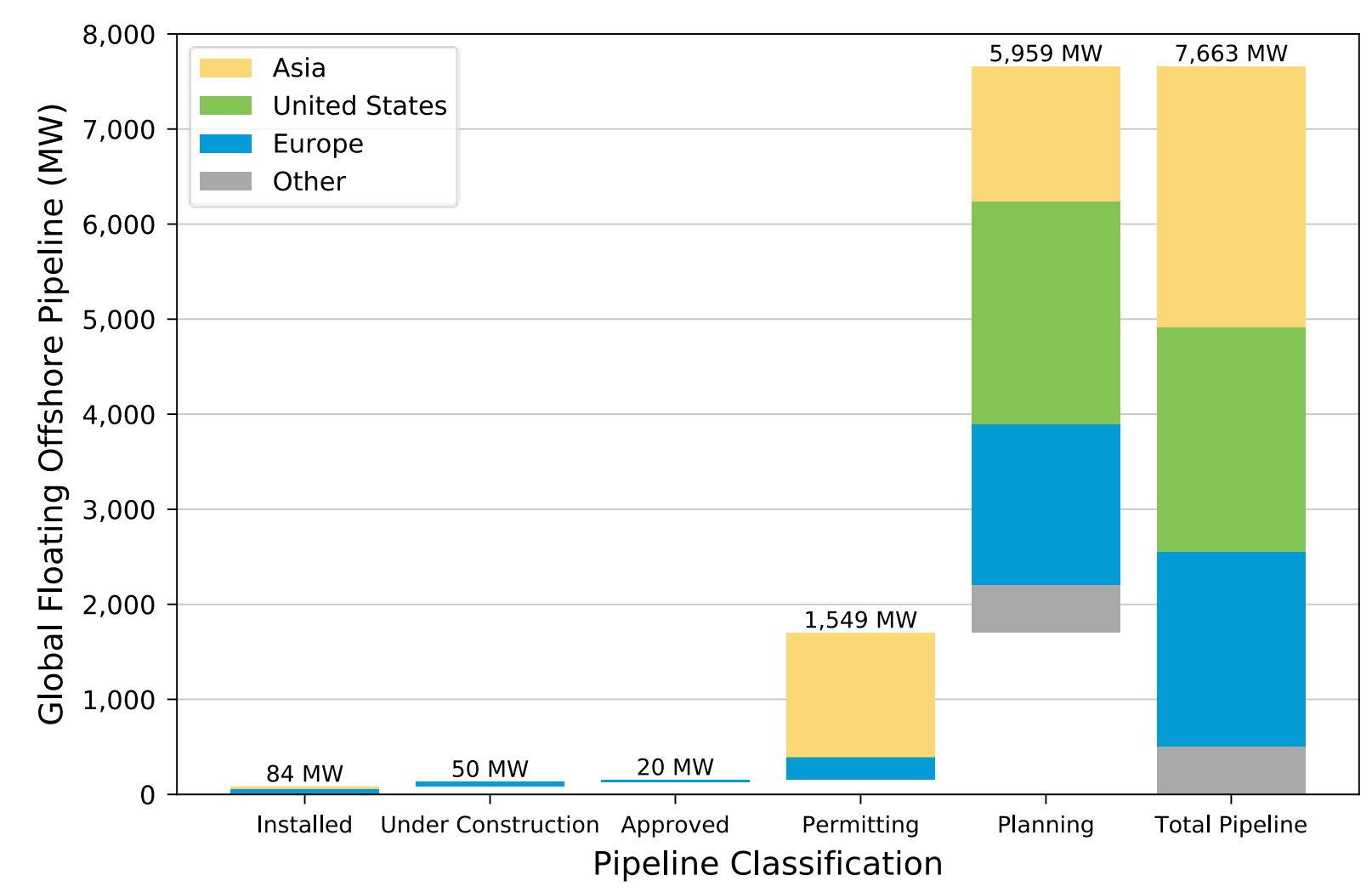

- $\quad$ The total global floating offshore wind pipeline was 7,663 MW at the end of 2019, based on projects that have announced their planned capacity.

- $\quad 1,549 \mathrm{MW}$ of floating offshore wind has reached the permitting stage.

- $\quad$ The 25.2-MW WindFloat Atlantic, the second floating project in Europe, became fully operational in 2020.

- The primary driver for pipeline expansion is the movement toward commercial-scale projects developing in Asia. 


\section{Floating Offshore Wind Pipeline}

\begin{tabular}{|c|c|c|c|c|c|c|c|}
\hline Region & Country & Installed (MW) & Under Construction (MW) & Approved (MW) & Permitting (MW) & Planning (MW) & Totals (MW) \\
\hline \multirow{4}{*}{ Asia } & China & 0 & 0 & 0 & 0 & 16 & 16 \\
\hline & Japan & 22.06 & 0 & 0 & 0 & 0 & 22.06 \\
\hline & South Korea & 0 & 0 & 0 & 1,300 & 406 & 1,706 \\
\hline & Taiwan & 0 & 0 & 0 & 0 & 1,000 & 1,000 \\
\hline Middle East & Saudi Arabia & 0 & 0 & 0 & 0 & 500 & 500 \\
\hline \multirow{8}{*}{ Europe } & France & 2 & 0 & 10 & 108.5 & 256 & 376.5 \\
\hline & Germany & 0 & 0 & 0 & 0 & 2.3 & 2.3 \\
\hline & Ireland & 0 & 0 & 0 & 0 & 706 & 706 \\
\hline & Norway & 2.9 & 0 & 10 & 101.6 & 0 & 114.5 \\
\hline & Portugal & 25 & 0 & 0 & 0 & 0 & 25 \\
\hline & Spain & 2.2 & 0 & 0.03 & 27 & 216.23 & 245.46 \\
\hline & Sweden & 0.03 & 0 & 0 & 0 & 1 & 1.03 \\
\hline & United Kingdom & 30 & 50 & 0 & 0 & 506 & 586 \\
\hline \multirow[t]{2}{*}{ North America } & United States & 0 & 0 & 0 & 12 & 2,350 & 2,362 \\
\hline & Totals & 84.19 & 50 & 20.03 & $1,549.1$ & $5,959.5$ & 7,663 \\
\hline
\end{tabular}

Note: Values are estimated on developer's announced plant capacity and only include projects with specified CODs. 


\section{Floating Offshore Wind Projects (Asia and the Middle East)}

\begin{tabular}{|c|c|c|c|c|c|c|c|c|}
\hline Project Name & Country & Status & COD & Project Size (MW) & Substructure Type & Substructure Name & Turbine & Site Water Depth (m) \\
\hline $\begin{array}{c}\text { Shanghai Electric } \\
\text { Floating Demonstrator }\end{array}$ & China & Planning & 2023 & 4 & TBD & TBD & TBD & TBD \\
\hline $\begin{array}{l}\text { V-Type Floating } \\
\text { Demonstration }\end{array}$ & China & Planning & 2023 & 12 & Spar & TBD & TBD & TBD \\
\hline Kyushu Wind Lens & Japan & Operational & 2012 & 0.06 & Steel semisubmersible & Wind Lens Floater & $\begin{array}{l}3 \text { kilowatts (kW) } \\
\text { (RIAMWIND) }\end{array}$ & 55 \\
\hline Fukushima Phase 1 & Japan & Operational & 2013 & 2 & Steel semisubmersible & Fukushima Mirai & 2 MW (Hitachi) & 120 \\
\hline Fukushima Phase 2 & Japan & Operational & 2015 & 7 & Steel semisubmersible & Fukushima Shimpuu & 7 MW (Mitsubishi) & 120 \\
\hline Fukushima Phase 2 & Japan & Operational & 2016 & 5 & Steel spar & Hamakaze Spar & $5 \mathrm{MW}$ (Hitachi) & 120 \\
\hline Goto Sakiyama & Japan & Operational & 2016 & 2 & Steel spar & Steel Spar & 2 MW (Hitachi) & 100 \\
\hline Hibiki Demo & Japan & Operational & 2018 & 3 & Barge & Ideol Damping Pool & $3 \mathrm{MW}$ (Aerodyn) & 55 \\
\hline Kitakyushu NEDO & Japan & Operational & 2019 & 3 & Barge & Ideol Damping Pool & $3 \mathrm{MW}$ (Aerodyn) & 100 \\
\hline Equinor-Hitachi Zosen & Japan & Planning & 2022 & $\begin{array}{l}\text { TBD (Commercial } \\
\text { Scale) }\end{array}$ & TBD & TBD & TBD & TBD \\
\hline Acacia & Japan & Planning & 2023 & $\begin{array}{l}\text { TBD (Commercial } \\
\text { Scale) }\end{array}$ & Barge & Ideol Dampening Pool & $8 \mathrm{MW}$ & TBD \\
\hline WindFloat Japan & Japan & Planning & TBD & TBD & Steel semisubmersible & PPI WindFloat & TBD & TBD \\
\hline Donghae Gray Whale & South Korea & Permitting & 2025 & 200 & TBD & TBD & TBD & 150 \\
\hline Donghae TwinWind & South Korea & Permitting & 2025 & 200 & $\begin{array}{l}\text { Multiturbine steel } \\
\text { semisubmersible }\end{array}$ & Hexicon & $20 \times 10 \mathrm{MW}$ & 150 \\
\hline KNOC/Equinor & South Korea & Permitting & 2026 & 200 & TBD & TBD & TBD & 150 \\
\hline Ulsan White Heron & South Korea & Permitting & 2026 & 200 & TBD & TBD & TBD & 150 \\
\hline Donghae - MOTIE & South Korea & Planning & 2022 & 200 & Steel semisubmersible & TBD & TBD & TBD \\
\hline Donghae 1 & South Korea & Planning & 2023 & 200 & Spar & TBD & TBD & TBD \\
\hline Ulsan Demos & South Korea & Planning & 2021 & 5.75 & Steel semisubmersible & TBD & TBD & TBD \\
\hline Floating W1N & Taiwan & Planning & 2025 & 500 & Steel semisubmersible & TBD & TBD & TBD \\
\hline EOLFI-W3 & Taiwan & Planning & 2030 & 500 & TBD & TBD & TBD & TBD \\
\hline Plambeck Emirates & Saudi Arabia & Planning & 2024 & 500 & Steel semisubmersible & Saipem HexaFloat & TBD & TBD \\
\hline
\end{tabular}

Note: Operational projects are in bold. Project size is based on developer announcements. 


\section{Floating Offshore Wind Projects (Europe)}

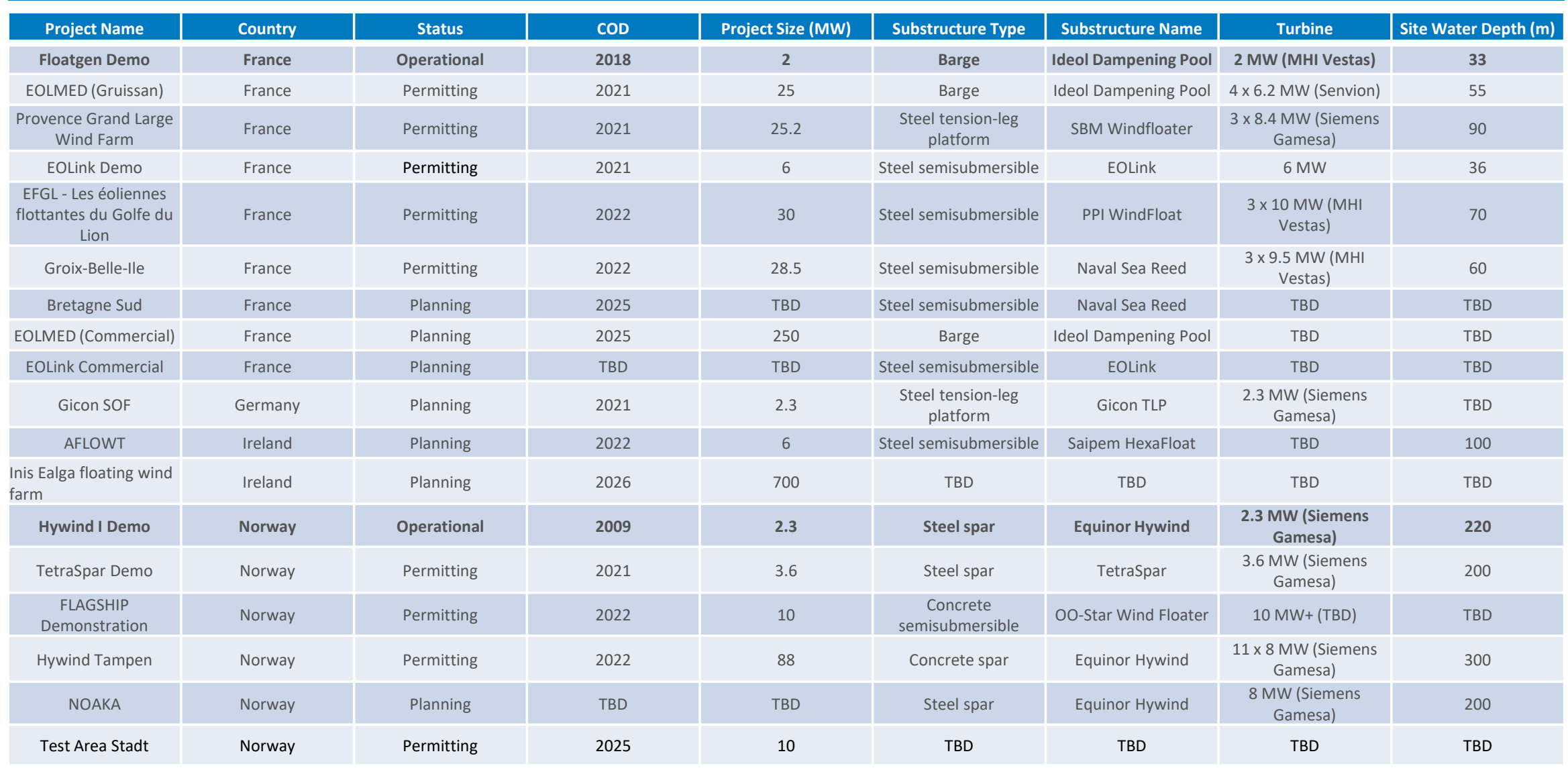

Note: Operational projects are in bold. Project size is based on developer announcements. 


\section{Floating Offshore Wind Projects (Europe [Continued])}

\begin{tabular}{|c|c|c|c|c|c|c|c|c|}
\hline Project Name & Country & Status & COD & Project Size (MW) & Substructure Type & Substructure Name & Turbine & Site Water Depth (m) \\
\hline WindFloat Atlantic & Portugal & Operational & 2020 & 25 & Steel semisubmersible & PPI WindFloat & $3 \times 8.3 \mathrm{MW}$ (MHI Vestas) & 100 \\
\hline W2Power & Spain & Operational & 2019 & 0.02 & Multiturbine steel semisubmersible & W2Power & $100 \mathrm{~kW}$ & 600 \\
\hline BlueSATH & Spain & Operational & 2020 & 0.03 & Concrete semisubmersible & SATH & Aeolos-H 30kW & 80 \\
\hline DemoSATH & Spain & Operational & 2020 & 2 & Concrete semisubmersible & SATH & 2 MW (XEMC Darwind) & 80 \\
\hline Floating Power Plant & Spain & Planning & 2021 & 8 & Hybrid wind-wave semisubmersible & P80 & $5 \mathrm{MW}+(\mathrm{TBD})$ & 600 \\
\hline FLOCAN 5 & Spain & Planning & 2024 & 25 & Steel semisubmersible & TBD & TBD & TBD \\
\hline $\mathrm{X} 1$ Wind & Spain & Permitting & 2021 & 2 & Steel tension-leg platform & PivotBuoy & $2 \mathrm{MW}$ (MHI Vestas) & 600 \\
\hline Nautilus/Balea & Spain & Planning & 2023 & 8 & Steel semisubmersible & Nautilus Semi-sub & $8 \mathrm{MW}(\mathrm{TBD})$ & 120 \\
\hline $\begin{array}{c}\text { Equinor Floating Project } \\
\text { (Juan Grande) }\end{array}$ & Spain & Planning & 2024 & 200 & Steel spar & Equinor Hywind & TBD & TBD \\
\hline Iberdrola Demo & Spain & Planning & TBD & TBD & TBD & TBD & TBD & TBD \\
\hline CanArray & Spain & Planning & TBD & TBD & Multiturbine steel semisubmersible & W2Power & $6 \mathrm{MW}$ (TBD) & 600 \\
\hline SeaTwirl 1 & Sweden & Operational & 2015 & 0.03 & Steel spar (VAWT*) & SeaTwirl & 30-kW VAWT & 35 \\
\hline SeaTwirl 2 & Sweden & Permitting & 2021 & 1 & Steel spar (VAWT) & SeaTwirl & 1-MW VAWT & 100 \\
\hline Hywind Scotland & UK & Operational & 2017 & 30 & Steel spar & Equinor Hywind & $6 \mathrm{MW}$ (Siemens Gamesa) & 112 \\
\hline Kincardine Phase 1 & UK & Operational & 2018 & 2 & Steel semisubmersible & PPI WindFloat & $2 \mathrm{MW}$ (MHI Vestas) & 62 \\
\hline Kincardine Phase 2 & UK & Under Construction & 2020 & 50 & Steel semisubmersible & PPI WindFloat & $5 \times 9.5 \mathrm{MW}$ (MHI Vestas) & 62 \\
\hline Marine Power Systems & UK & Planning & 2023 & TBD & $\begin{array}{l}\text { Wind-wave hybrid steel } \\
\text { semisubmersible }\end{array}$ & DualSub & TBD & TBD \\
\hline Dolphyn Phase 1 & UK & Planning & 2024 & 2 & Steel semisubmersible & $\begin{array}{l}\text { PPI WindFloat } \\
\text { +Electrolyzer }\end{array}$ & $2 \mathrm{MW}$ (MHI Vestas) & TBD \\
\hline Erebus & UK & Planning & 2025 & 96 & Steel semisubmersible & PPI WindFloat & TBD & 70 \\
\hline Dolphyn Phase 2 & UK & Planning & 2027 & 400 & Steel semisubmersible & $\begin{array}{l}\text { PPI WindFloat } \\
\text { +Electrolyzer }\end{array}$ & $10 \mathrm{MW}$ & TBD \\
\hline Dounreay Tri & UK & Planning & TBD & 10 & Multiturbine steel semisubmersible & Hexicon & $5 \mathrm{MW}$ (TBD) & TBD \\
\hline Katanes Floating Energy Park & UK & Planning & 2022 & 8 & Hybrid wind-wave semisubmersible & P80 & $5 \mathrm{MW}+(\mathrm{TBD})$ & TBD \\
\hline Dyfed Floating Energy Park & UK & Planning & TBD & TBD & Hybrid wind-wave semisubmersible & P80 & $5 \mathrm{MW}+(\mathrm{TBD})$ & TBD \\
\hline
\end{tabular}




\section{Floating Offshore Wind Projects (North America)}

\begin{tabular}{|c|c|c|c|c|c|c|c|c|}
\hline Project Name & Country & Status & COD & Project Size (MW) & Substructure Type & Substructure Name & Turbine & Site Water Depth (m) \\
\hline Aqua Ventus & United States & Permitting & 2023 & 12 & $\begin{array}{c}\text { Concrete } \\
\text { semisubmersible }\end{array}$ & VolturnUS & $10 \mathrm{MW}+(\mathrm{TBD})$ & 100 \\
\hline Castle Wind & United States & Planning & TBD & 1,000 & $\begin{array}{c}\text { Steel } \\
\text { semisubmersible }\end{array}$ & TBD & TBD & 900 \\
\hline Magellan Stiesdal & United States & Planning & TBD & TBD & $\begin{array}{c}\text { Steel } \\
\text { semisubmersible }\end{array}$ & TetraSpar & TBD & TBD \\
\hline Oahu North & United States & Planning & TBD & 400 & $\begin{array}{c}\text { Steel } \\
\text { semisubmersible }\end{array}$ & TBD & TBD & 850 \\
\hline Oahu South & United States & Planning & TBD & 400 & $\begin{array}{c}\text { Steel } \\
\text { semisubmersible }\end{array}$ & TBD & TBD & 650 \\
\hline Progression South & United States & Planning & TBD & 400 & $\begin{array}{c}\text { Steel } \\
\text { semisubmersible }\end{array}$ & TBD & TBD & 600 \\
\hline Redwood Coast & United States & Planning & TBD & 150 & $\begin{array}{c}\text { Steel } \\
\text { semisubmersible }\end{array}$ & PPI WindFloat & $8 \mathrm{MW}+(\mathrm{TBD})$ & 600 \\
\hline
\end{tabular}




\section{Global Floating Offshore Wind Project Timeline for Projects with Announced CODs}

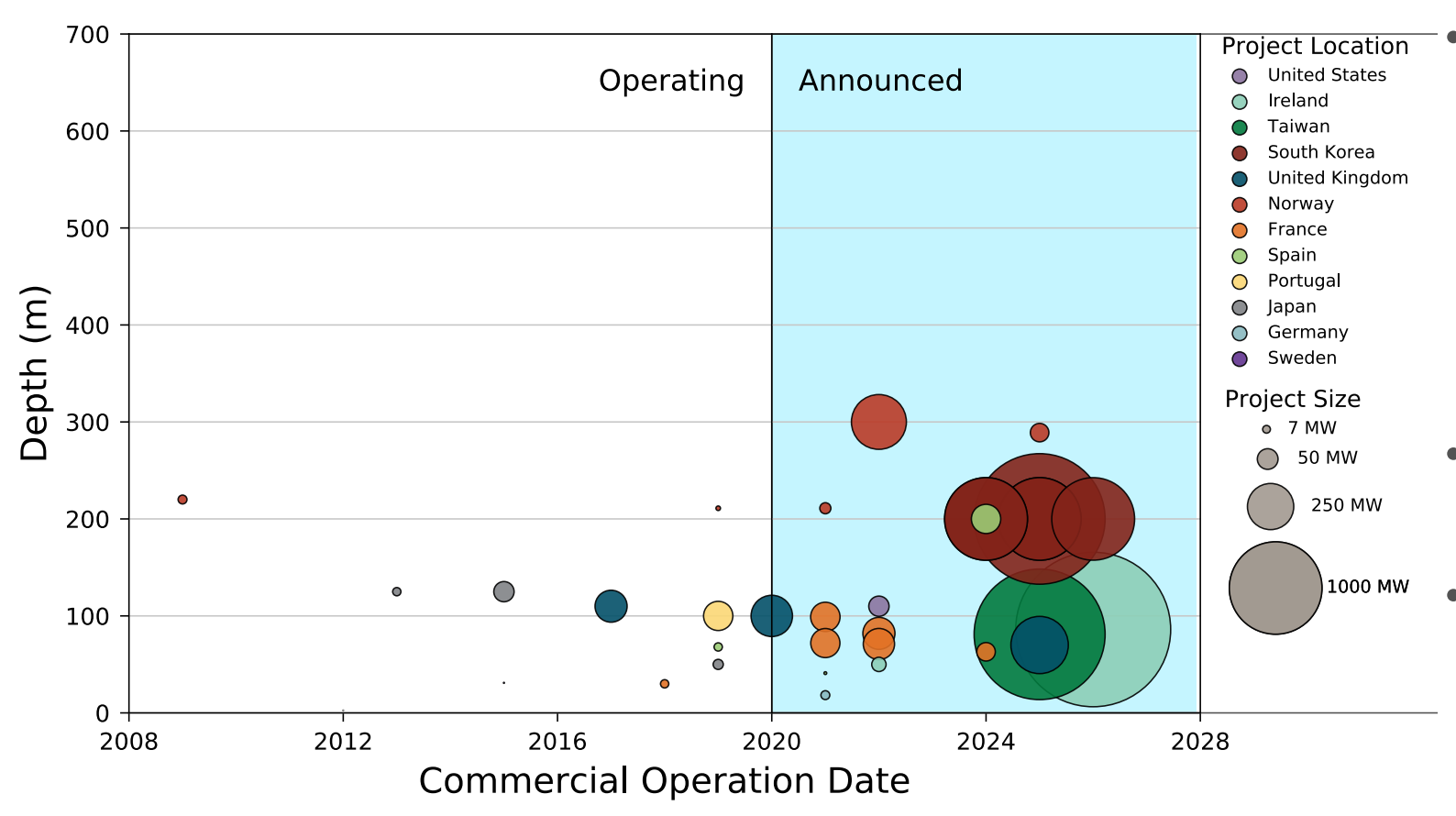

- There are roughly 12 projects (292 MW) that are under construction or in the permitting phase in Europe, which are scheduled for commercial operations between 2020 and 2022.

- There are $1,300 \mathrm{MW}$ of projects in the permitting phase in Asia.

- Several projects have been announced without an anticipated commercial operation date. These projects are not shown on the chart. 


\section{Cumulative Offshore Floating Wind Capacity by Country Based on Announced COD Through 2025}

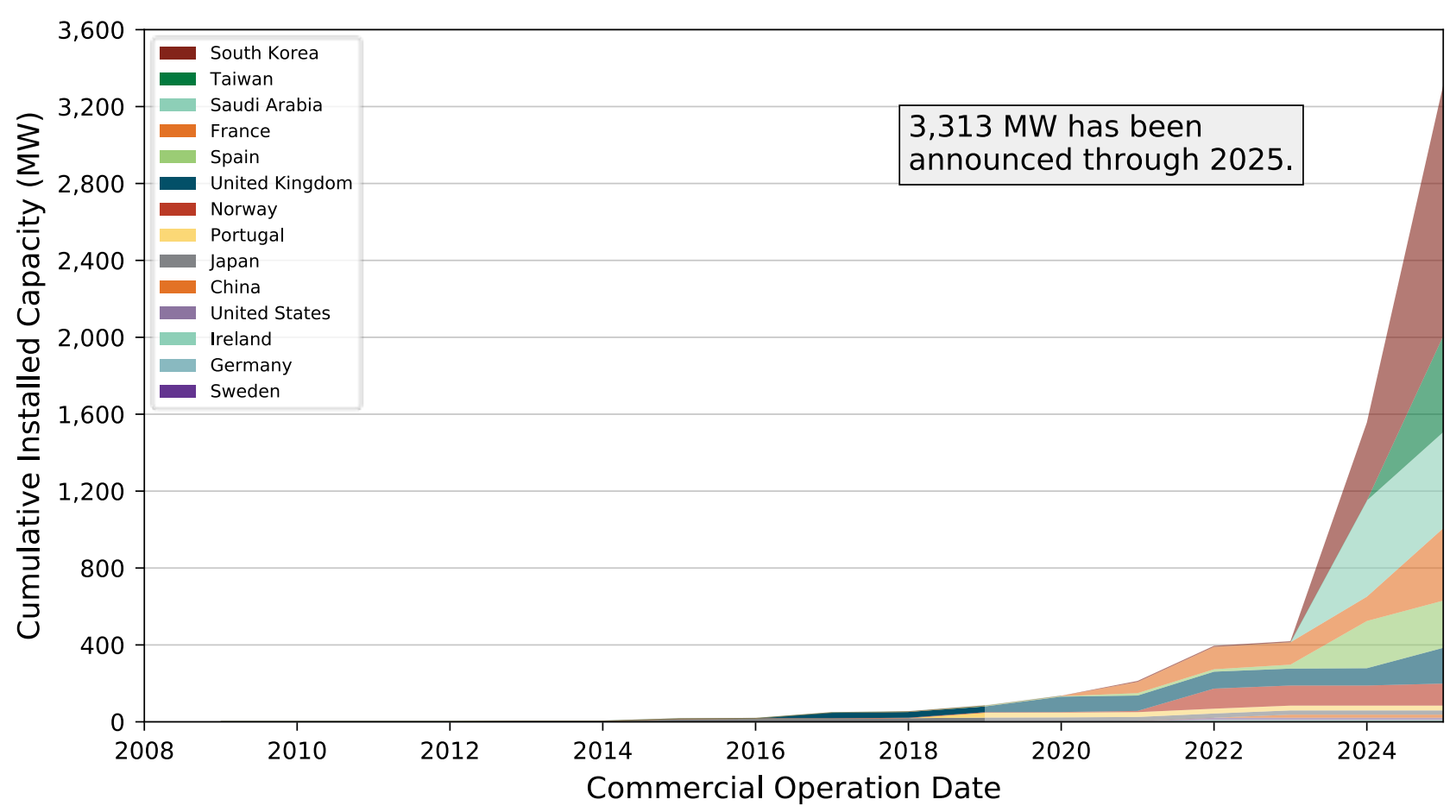

- Projects with announced CODs in 2025 or before total 3,313 MW.

- A small number of commercial projects have announced a COD after 2025.

- Aqua Ventus I is the only U.S. project in the permitting stage and is now expected to reach commercial operations in 2023. 


\section{Country-Specific Offshore Floating Wind Capacity Based on Announced COD Through 2025}

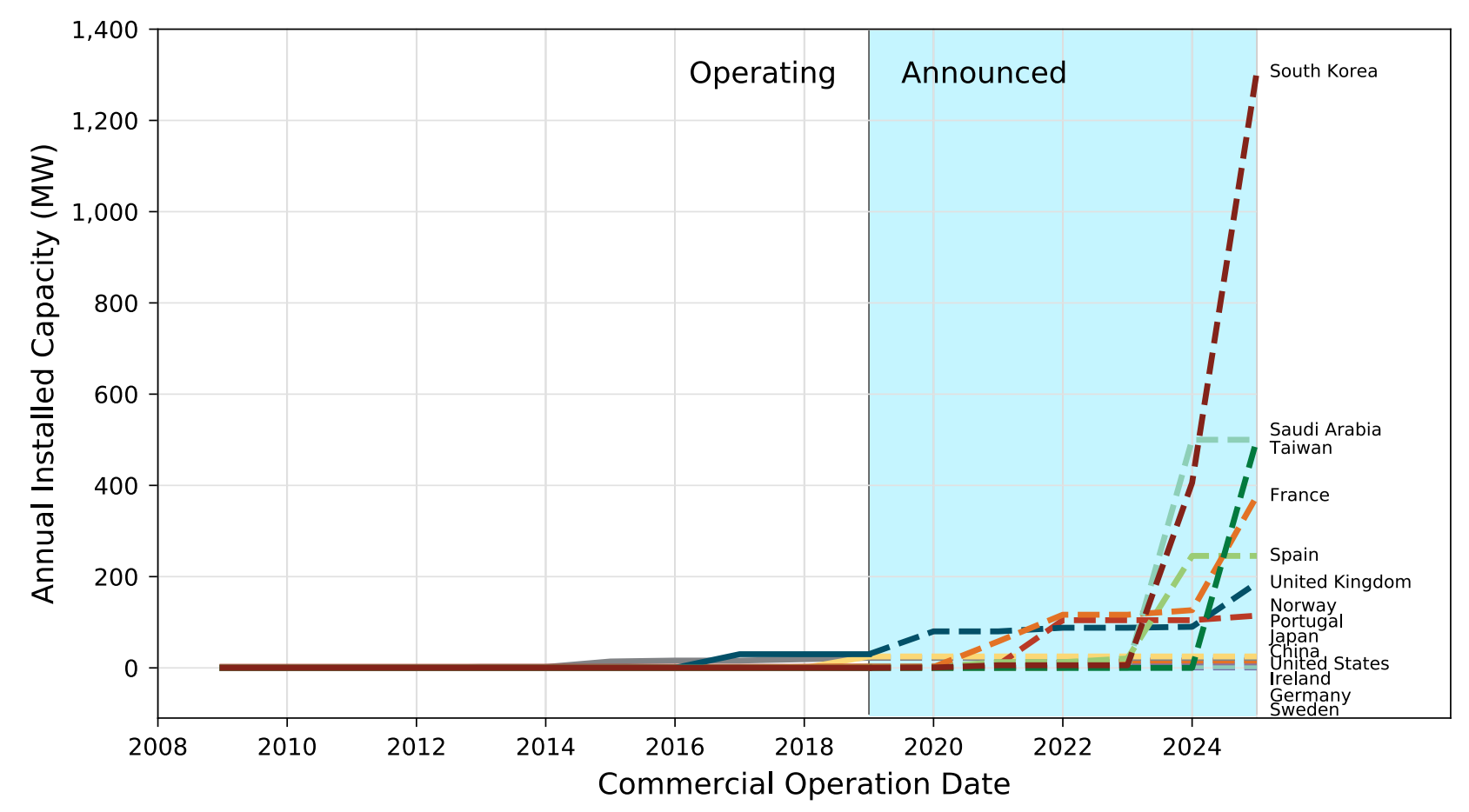

- Korea, France, Taiwan, Spain, and the UK account for the majority of announced CODs through 2025, with several commercial-scale projects announced for 2024.

- $\quad$ Pilot-scale projects (less than $50 \mathrm{MW}$ ) account for nearly all floating projects with announced CODs through 2023. 
2019 Offshore Wind
Technology Trends

2019 Offshore Win
Technology Trends 


\section{Fixed-Bottom Offshore Wind Project Depths and Distances to Shore}

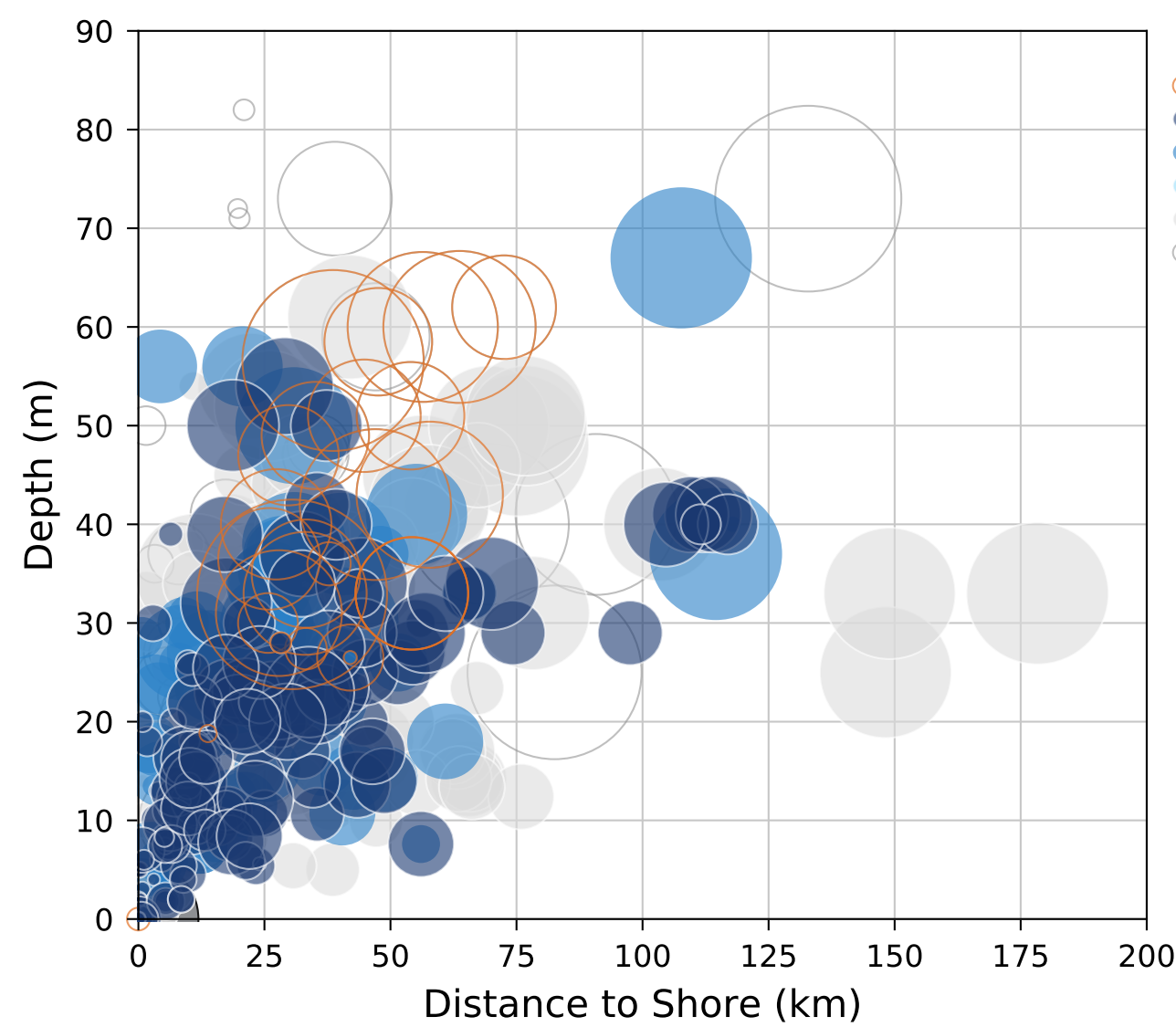

Project Status

U.S. Projects

Installed

Under Construction

Contracted

Approved

Permitting/Site Control

\section{Project Size}

○ $7 \mathrm{MW}$

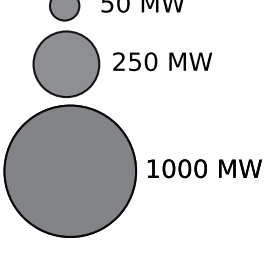

- Distance to shore is measured as the straightline distance between the project and the shoreline.

- Announced European projects indicate increasing project size, water depth, and distance to shore.

- Announced U.S. projects have not been proposed farther than 75 kilometers $(\mathrm{km})$ from shore but may push into water depths above $50 \mathrm{~m}$. 


\section{Distance from Shore for Operating and Future Projects}

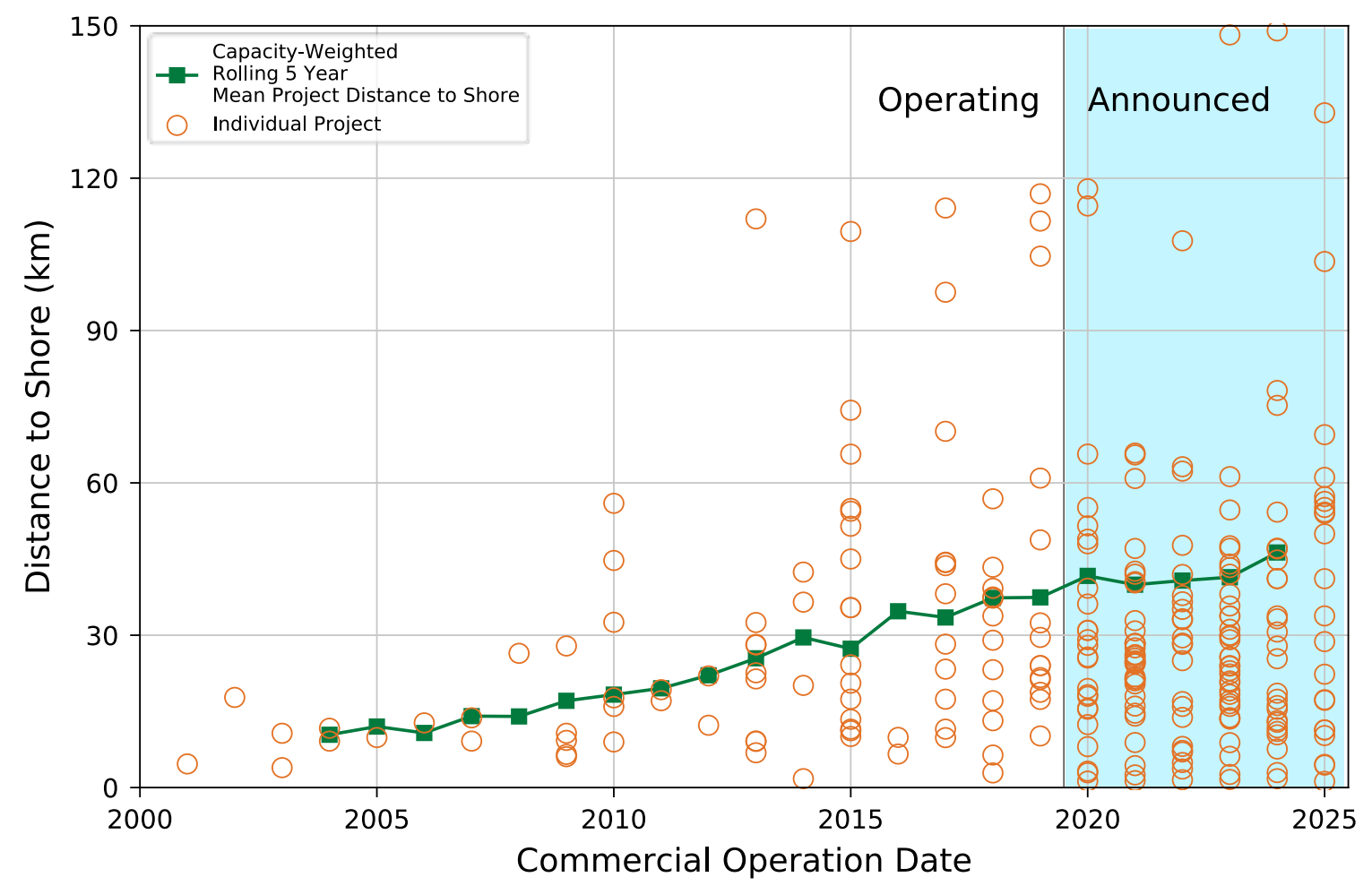

- The green line, showing the capacity-weighted rolling average, indicates that, on average, projects are trending farther from shore globally.

- Most announced projects remain between $0 \mathrm{~km}$ and 60 $\mathrm{km}$ from shore.

- The capacity-weighted mean is slowly moving further away from shore driven by a few large projects between $90 \mathrm{~km}$ and $150 \mathrm{~km}$. 


\section{Water Depth for Operating and Future Projects}

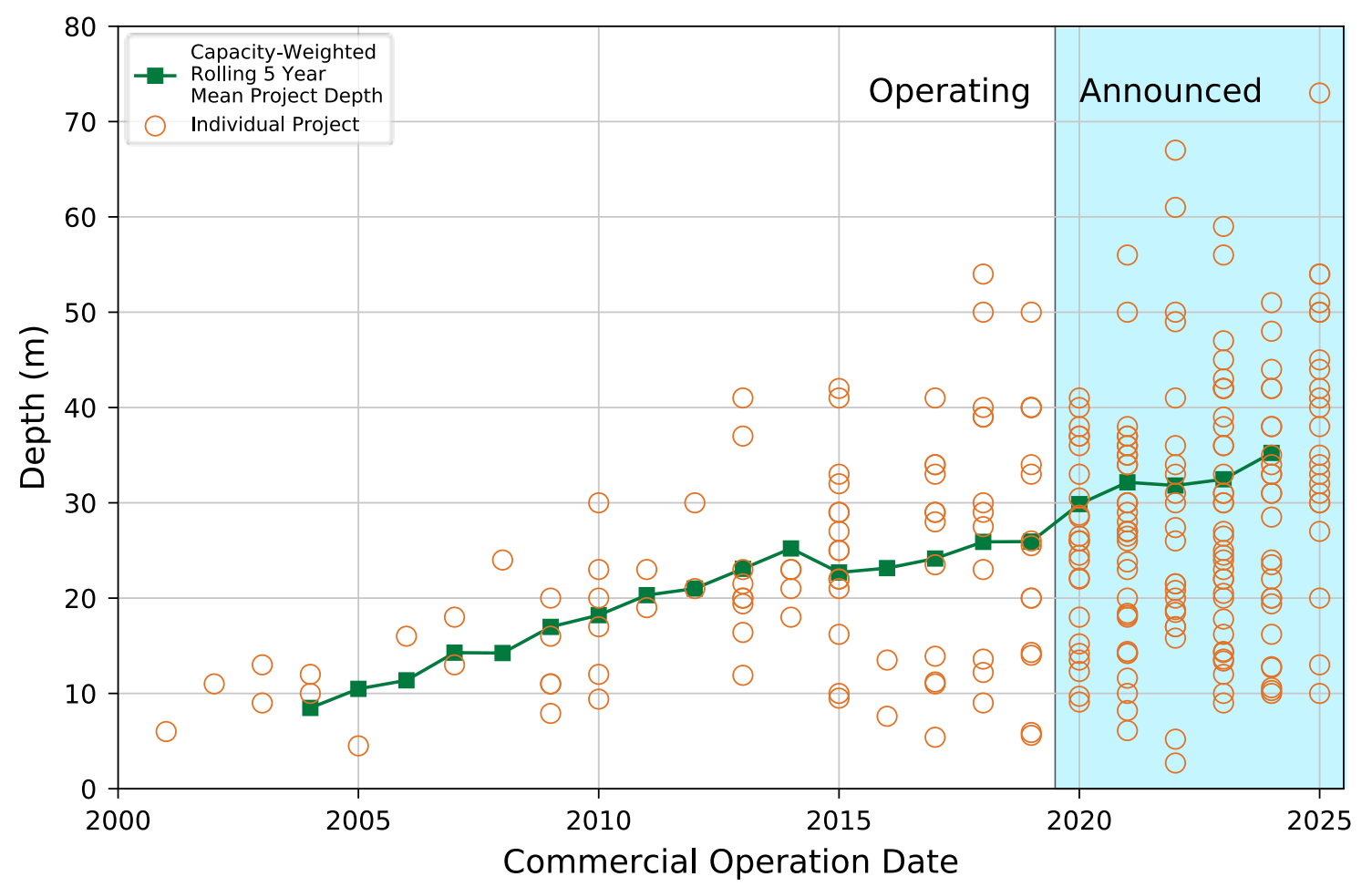

- The depth of water in which projects are installed is increasing.

- Green line shows capacityweighted 5-year mean project depth is driven upward by some announced projects that are planned for depths of $60 \mathrm{~m}$ and greater.

- Data indicate that fixed-bottom foundations may be economical in deeper waters than previously thought (Musial et al. 2016). 


\section{Average Offshore Wind Turbine Capacity, Hub Heights, and Rotor Diameters}

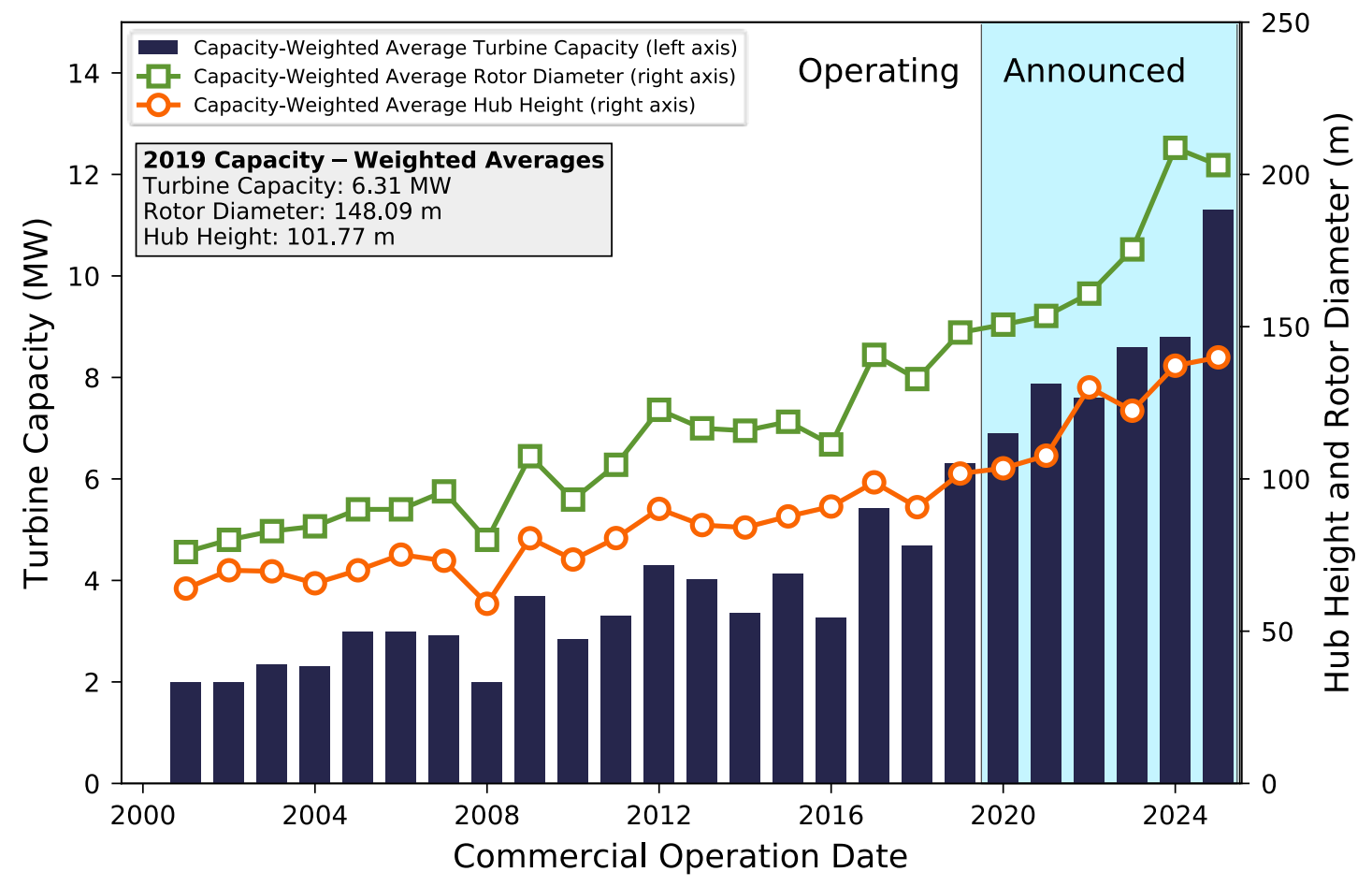

- $\quad$ Announced turbine supply agreements indicate continued growth in offshore turbine capacity, height, and rotor diameter.

- Data show average installed turbine capacity was about $6 \mathrm{MW}$ in 2019 and $11 \mathrm{MW}$ for projects announced for 2025.

- 12-MW turbines have been announced for some projects as early as 2023. 


\section{Comparison of Offshore Wind Turbine Prototypes with Commercial Offshore Turbine Growth}



- Data show year of first deployment for offshore wind turbine prototypes compared with commercial capacityweighted averages.

- Data indicate a multiyear lag before capacity-weighted averages reach prototype capacity levels.

- Progress in 12-MW to 14-MW prototype development was made in 2019.

- GE 12-MW Haliade-X prototype was installed onshore in Rotterdam in 2019.

- Siemens Gamesa announced the 10MW SG 10.0-193 direct-drive turbine and the 14-MW SG 14-222 turbine. 


\section{Offshore Wind Turbine Manufacturer Market Share in Operating Projects}



- In operating projects for which the turbine manufacturer is known:

- Siemens Gamesa continues to be the largest global supplier of offshore wind turbines, with about $58 \%$ of installed capacity $(14,311 \mathrm{MW})$.

- MHI Vestas has about 18\%market share of installed offshore wind capacity.

- The "Other" category includes offshore wind turbine manufacturers with less than a $60-\mathrm{MW}$ share of the market.

- The "Unreported" category comprises the capacity of projects where turbine data are not available. 


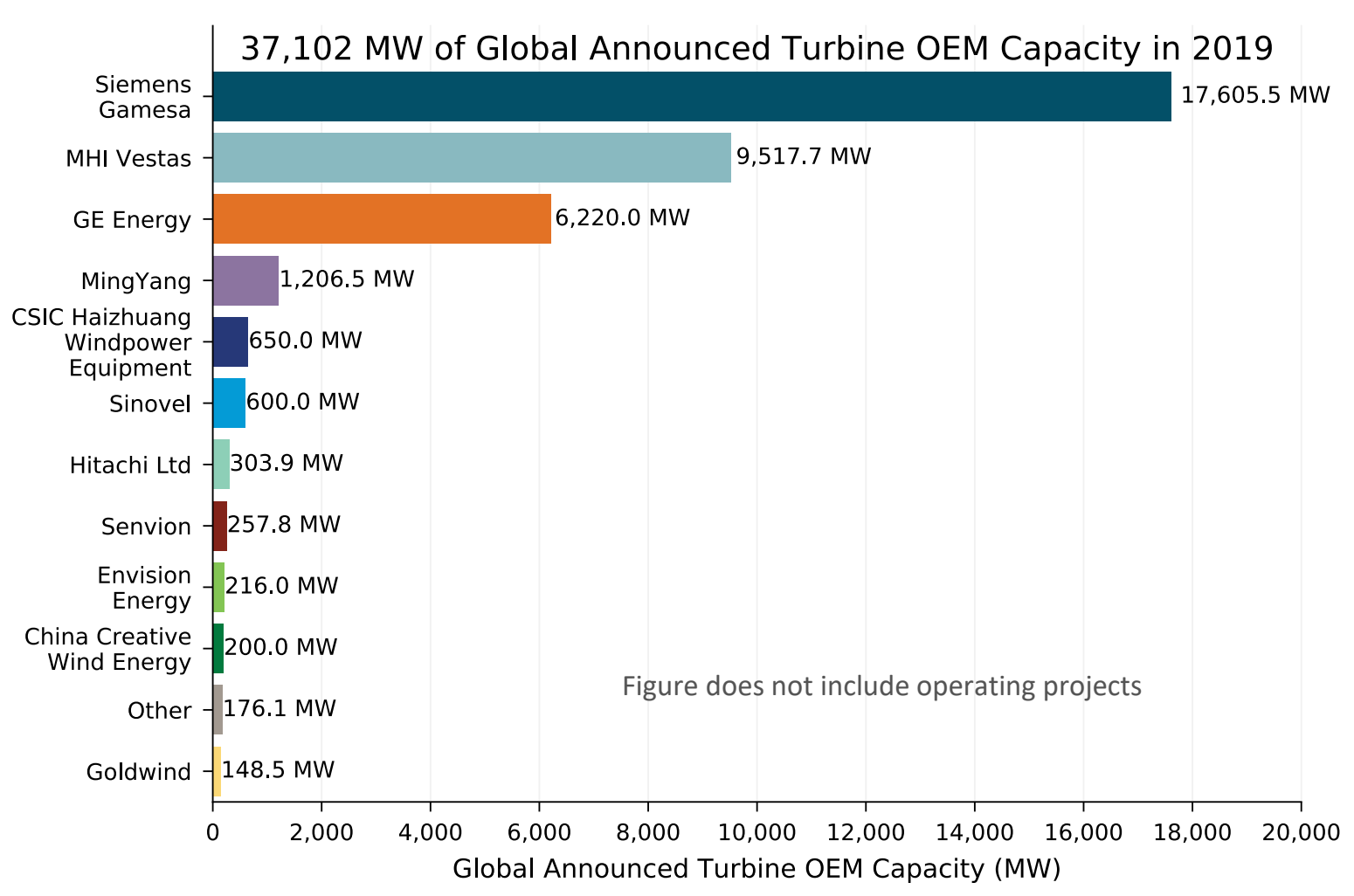

- $\quad$ Siemens Gamesa accounts for $47 \%$ of projects with announced turbine supply agreements.

- The MHI Vestas share is growing, with a $26 \%$ share of announced projects versus $18 \%$ of operating projects.

- $\quad$ GE's share is growing from $2 \%$ currently to $17 \%$ of announced projects.

- $166,008 \mathrm{MW}$ of announced project capacity has not reported a turbine original equipment manufacturer (OEM). 


\section{Offshore Wind Substructure Technology Used in Operating Projects}

Monopiles represented 75\% of total installed offshore wind capacity globally at the end of 2019

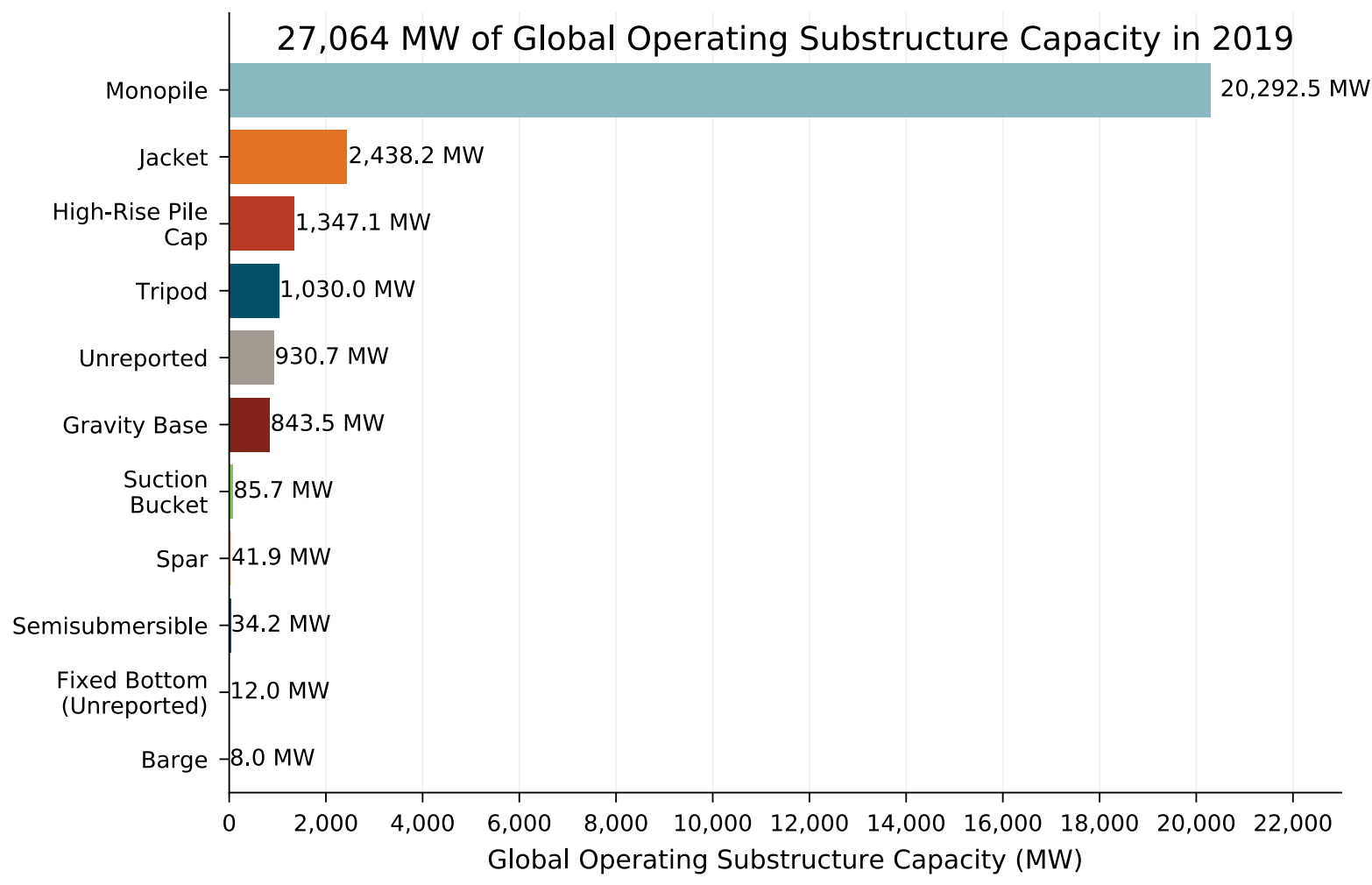




\section{Announced Offshore Wind Substructure Technology Market Share}

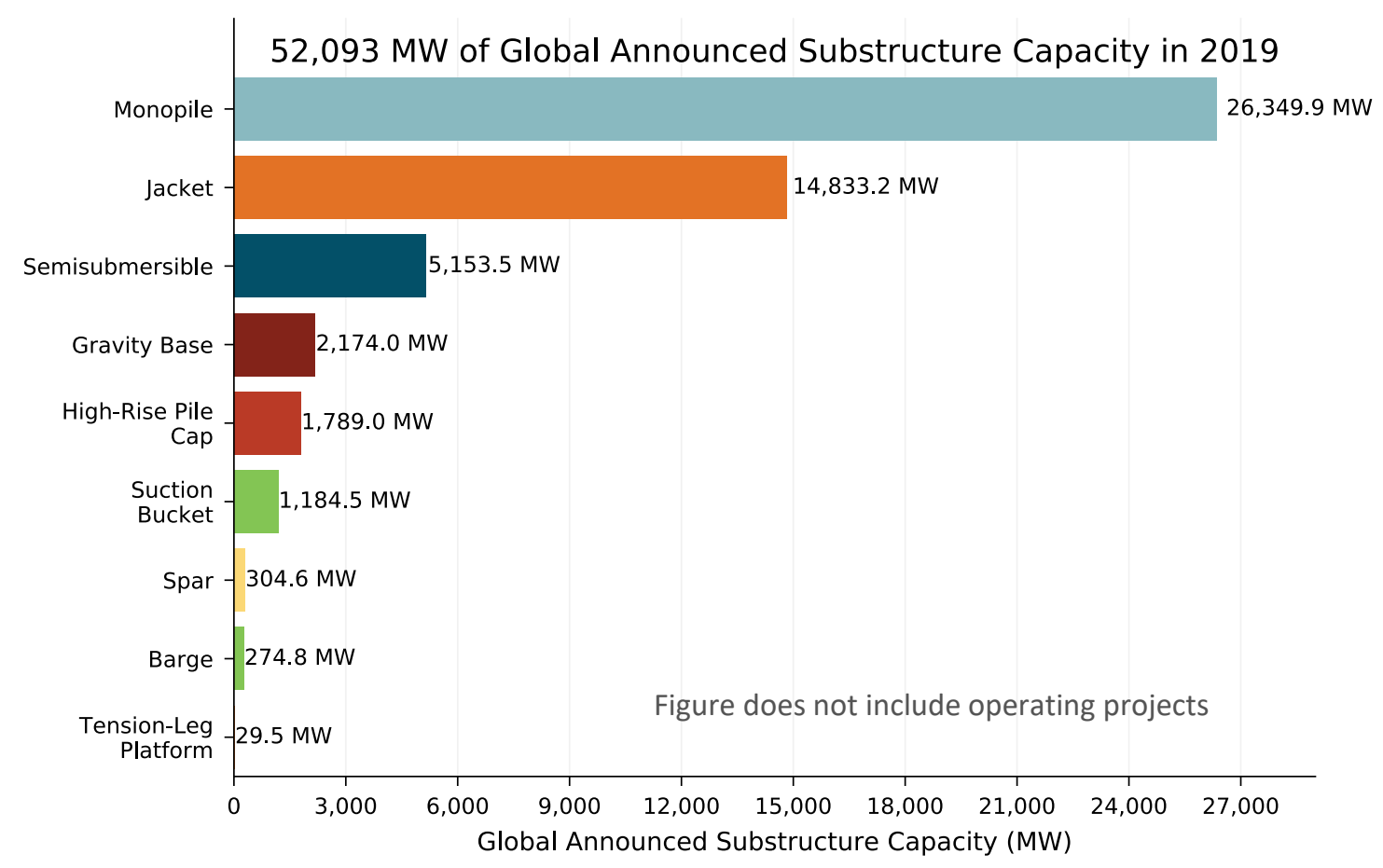

- $74 \%$ of announced projects $(151,017 \mathrm{MW})$ in the pipeline have not announced the substructure type.

- $51 \%$ of substructures for announced projects are monopiles, lower than the $75 \%$ share among operating projects.

- For depths greater than $60 \mathrm{~m}$, the industry is developing multiple types of floating substructures. 


\section{Global Floating Substructure Market Share}

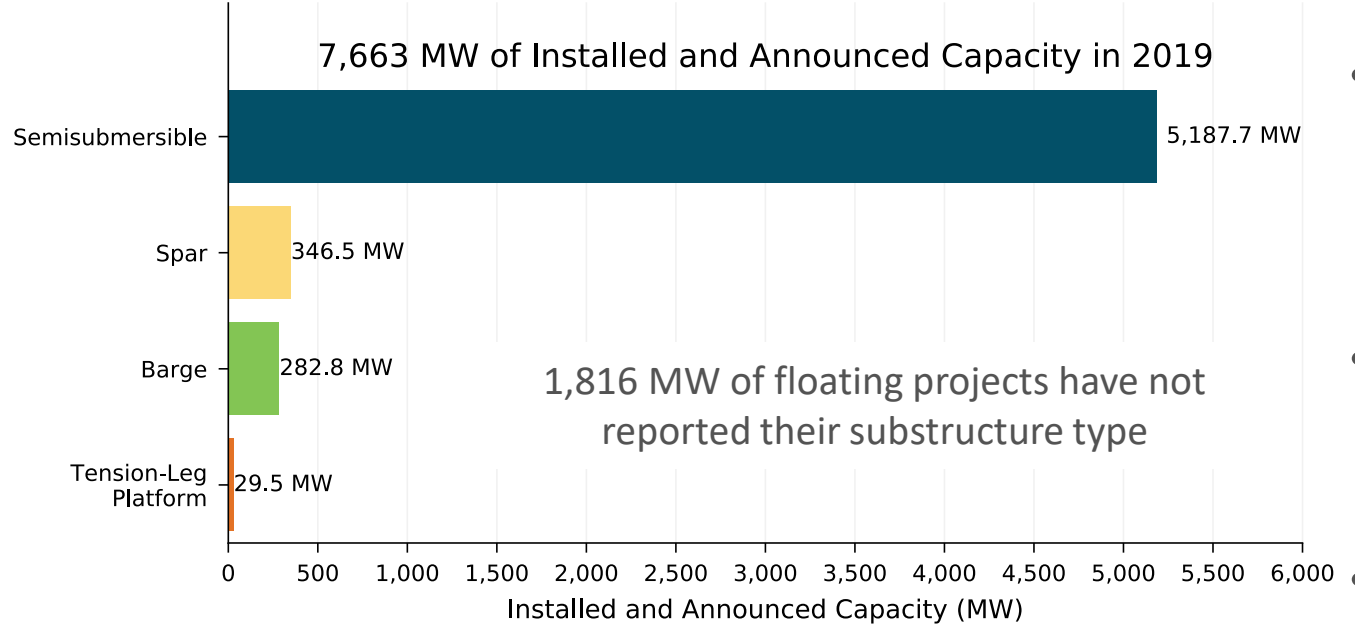

- In 2019, there were 7,663 MW of projects in the floating pipeline; the substructure type is announced for roughly $76 \%(5,847 \mathrm{MW})$ of the total pipeline.

- Semisubmersibles account for about $89 \%$ of installed and announced capacity for projects which the intended substructure type is known.

Semisubmersibles have shallow draft, which allows for full assembly and commissioning at


quayside, as well as tow-out to an offshore station without the use of heavy-lift installation vessels.

- Approximately $5 \%$ use or plan to use spars (e.g., Equinor's 30-MW floating wind power plant).

- The remaining substructures are tension-leg platforms and barges. 


\section{Offshore Subsea Cables Market Forecast}

BVG estimates array cables market will grow from $€ 0.4$ (\$0.4) billion in 2020 to $€ 0.8$ (\$0.9) billion in 2024.

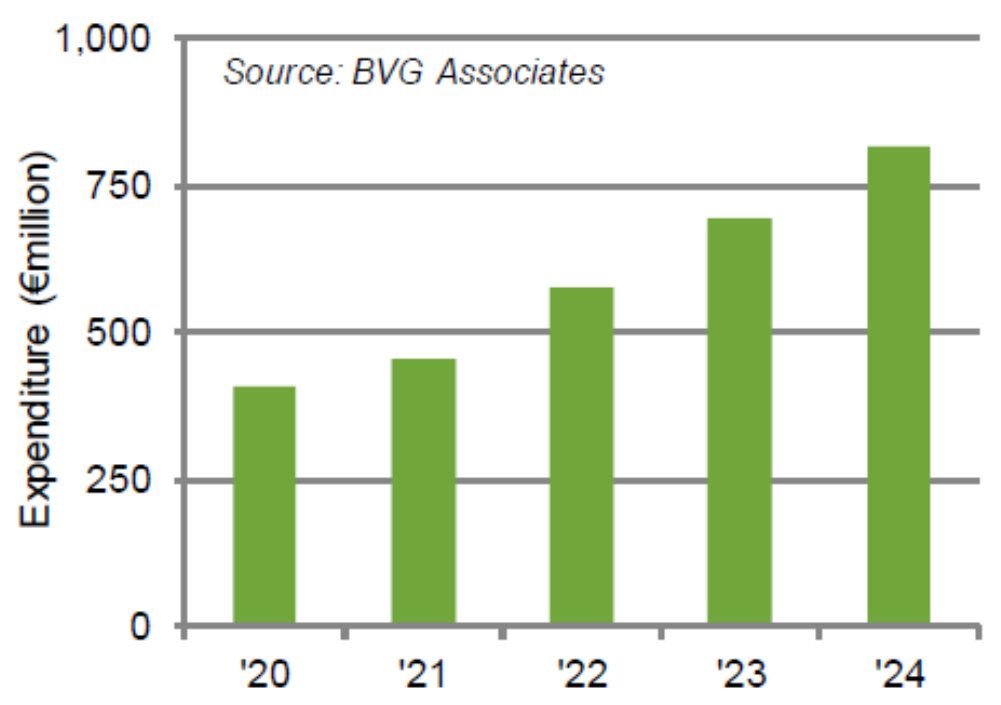

BVG estimates export cables market will grow from $€ 1.2$ (\$1.3) billion in 2020 to $€ 2.4$ (\$2.7) billion in 2024.

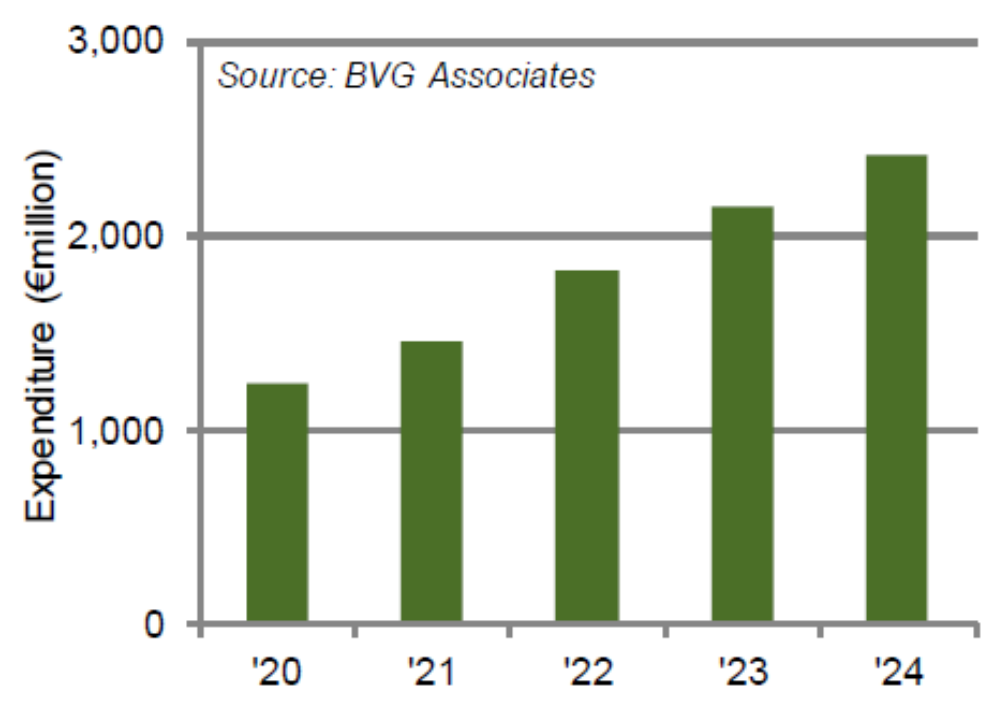




\section{Global Turbine Installation Vessel Fleet}



\footnotetext{
Turbine Model
}

Siemens SWT-6.0-154

Vestas V164-8.0

SG 10.0-193

GE Haliade- $X$

\begin{tabular}{|l|l} 
\\
Sieme
\end{tabular}

Manufacture

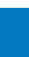

I

Rating
(MW)

\begin{abstract}
Rating
\end{abstract}
Siemens Gamesa

6

$$
\text { Vestas }
$$

8

Siemens Gamesa

General Electric

10

Nacelle Mass
(t)

Hub Height
(m)

225

N/A

12

15

\begin{tabular}{c}
$\begin{array}{c}\text { Rotor } \\
\text { Diameter } \\
(\mathbf{m})\end{array}$ \\
\hline 154 \\
\hline 164 \\
193 \\
\hline 220 \\
\hline 240
\end{tabular}

- With the introduction of the next generation of $12-\mathrm{MW}$ to $15-\mathrm{MW}$ wind turbines, the number of TIVs in the global fleet capable of installing these turbines diminishes significantly. ${ }^{1}$

- Lift height requirements are the most constraining factor. ${ }^{2}$

- New TIVs will be required to install and service the next generation of turbines both globally and in the United States.

${ }^{1}$ Some upcoming vessels are not included in this figure, as the maximum hook height or maximum lifting capacity have not been announced.

${ }^{2}$ This figure assumes a hub height sufficient for $30 \mathrm{~m}$ of water clearance at the lowest point of blade passage.

${ }^{3}$ The International Energy Agency (IEA) Wind 15-MW reference wind turbine (RWT) is a hypothetical wind turbine developed within the IEA Wind Task 37 (Gaertner et al. 2020). 


\section{Summary - Technology}

- Globally, the capacity-weighted average offshore wind turbine size has grown from $3.5 \mathrm{MW}$ in 2010 to $6 \mathrm{MW}$ in 2019. Similarly, rotor diameters have grown from a capacity-weighted average of $100 \mathrm{~m}$ in 2010 to $150 \mathrm{~m}$ in 2019. Announced turbine supply agreements for projects to be installed by 2025 show an increase in capacity to $10 \mathrm{MW}$ and rotor diameter to $200 \mathrm{~m}$.

- GE's Haliade-X 12-MW wind turbine prototype with a 220-m rotor was installed in Rotterdam, Netherlands, in fall 2019. GE reports that it will be commercially available in 2021.

- Siemens Gamesa announced that its 10-MW wind turbine prototype, with a 193-m rotor and a direct-drive generator, was installed in Osterild, Denmark, and will be commercially available in 2022.

- In May 2020, Siemens Gamesa also announced a new 14-MW turbine platform with a 222-m rotor and a direct-drive generator, which will be commercially available by 2024 .

- Technology advancements in fixed-bottom substructures have enabled siting in deeper water. In 2019, capacity-weighted average depth of installed projects was $31 \mathrm{~m}$. Project announcements indicate an increase in average depths to $43 \mathrm{~m}$ by 2025 . 


\section{Summary - Technology (continued)}

- The capacity-weighted distance from shore in 2019 was $47 \mathrm{~km}$ for installed projects. Project announcements indicate an increase to $70 \mathrm{~km}$ by 2025. More remote siting has been enabled by technology advancements in electrical grid infrastructure, such as high-voltage direct current (HVDC).

- In 2019, Siemens Gamesa and MHI Vestas were the two largest turbine suppliers, representing $53 \%$ and $16 \%$ of installed capacity, respectively. Of the projects that have announced turbine suppliers through 2025, Siemens Gamesa continues to hold the largest market share at $47 \%$, with $\mathrm{MHI}$ Vestas at $26 \%$ and GE at $17 \%$.

- Monopiles were used in 75\% of installed fixed-bottom global capacity in 2019 while jackets accounted for $9 \%$. The remainder of installations used various foundation types including high-rise pile cap, tripod, and gravity base.

- Hybrid versions of spars and tension-leg platform substructure types that achieve the same installation and commissioning benefits as semisubmersibles have been permitted in Europe and have announced deployment dates for pilot-scale demonstration in 2021 and 2022. 
2019 Offshore Wind Cost Data



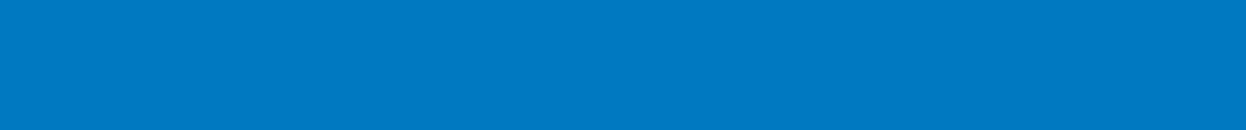

$\bar{x}$

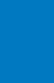

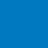
(1)






\section{Adjusted Strike Prices from U.S. and European Offshore Wind Auctions}

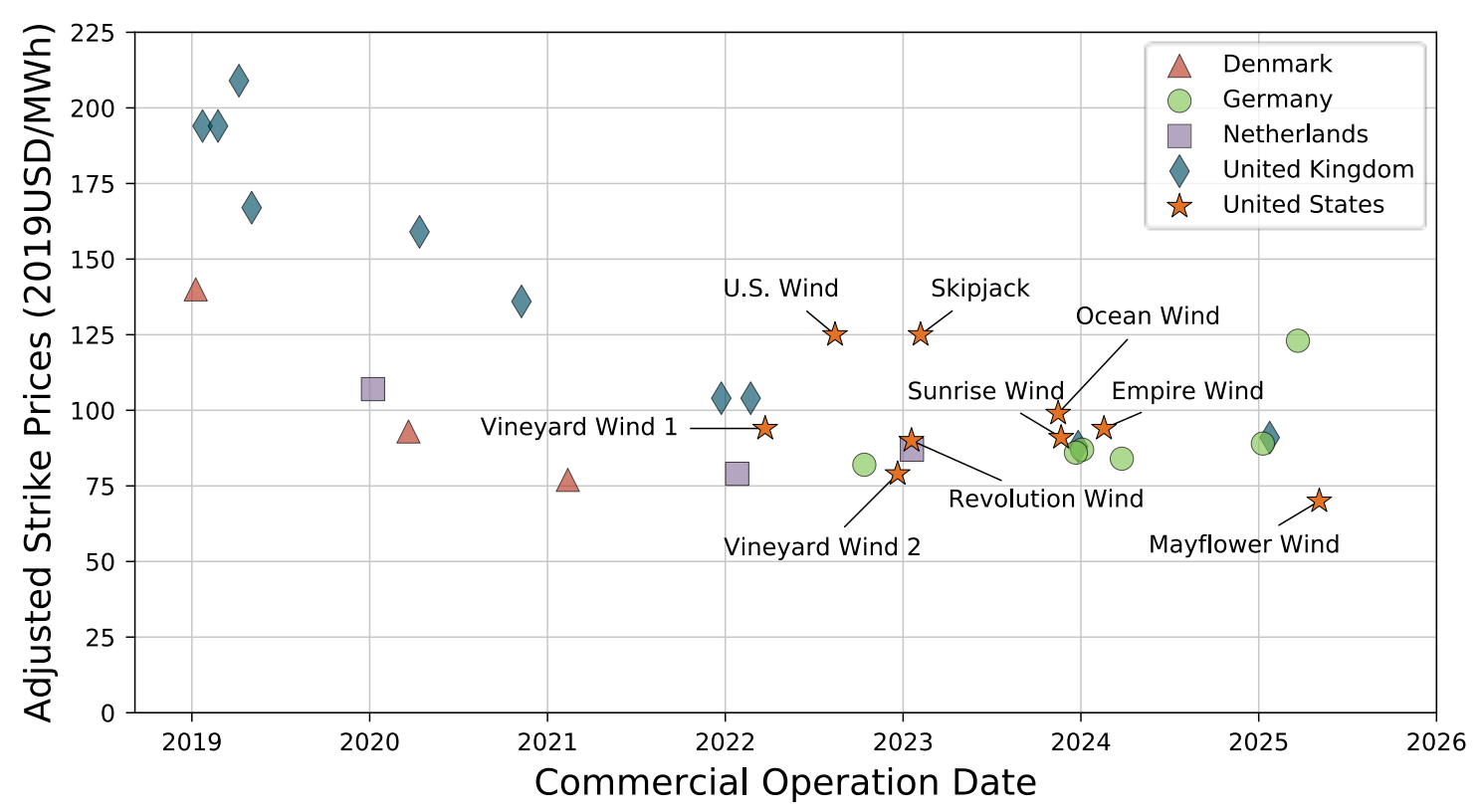

- In Europe, levelized adjusted ${ }^{4}$ PPA/OREC strike prices have fallen from around $\$ 180 /$ megawatt-hour (MWh) (2019 COD) to $\$ 90 / M W h$ (2025 COD) on average; a decrease of $50 \%$.

- $\quad$ Levelized power purchase agreement (PPA)/offshore renewable energy certificate (OREC) prices for U.S. projects have fallen by $40 \%$ over 2 years to $\$ 91 / \mathrm{MWh}$ on average, based on a total of 11 signed offtake agreements (with project COD between 2022 and 2025) by the end of 2019.

- With an adjusted PPA/OREC price of $\$ 69 / \mathrm{MWh}$, the Mayflower Wind project is among the lowest-priced announced offshore wind projects globally.

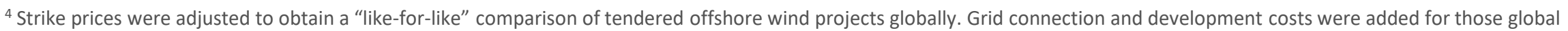

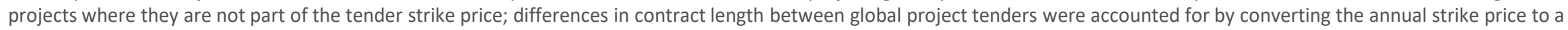
present value. The strike prices are shown in "levelized" terms (i.e., in terms of annualized \$/MWh). 


\section{Global LCOE Estimates for Fixed-Bottom Offshore Wind}

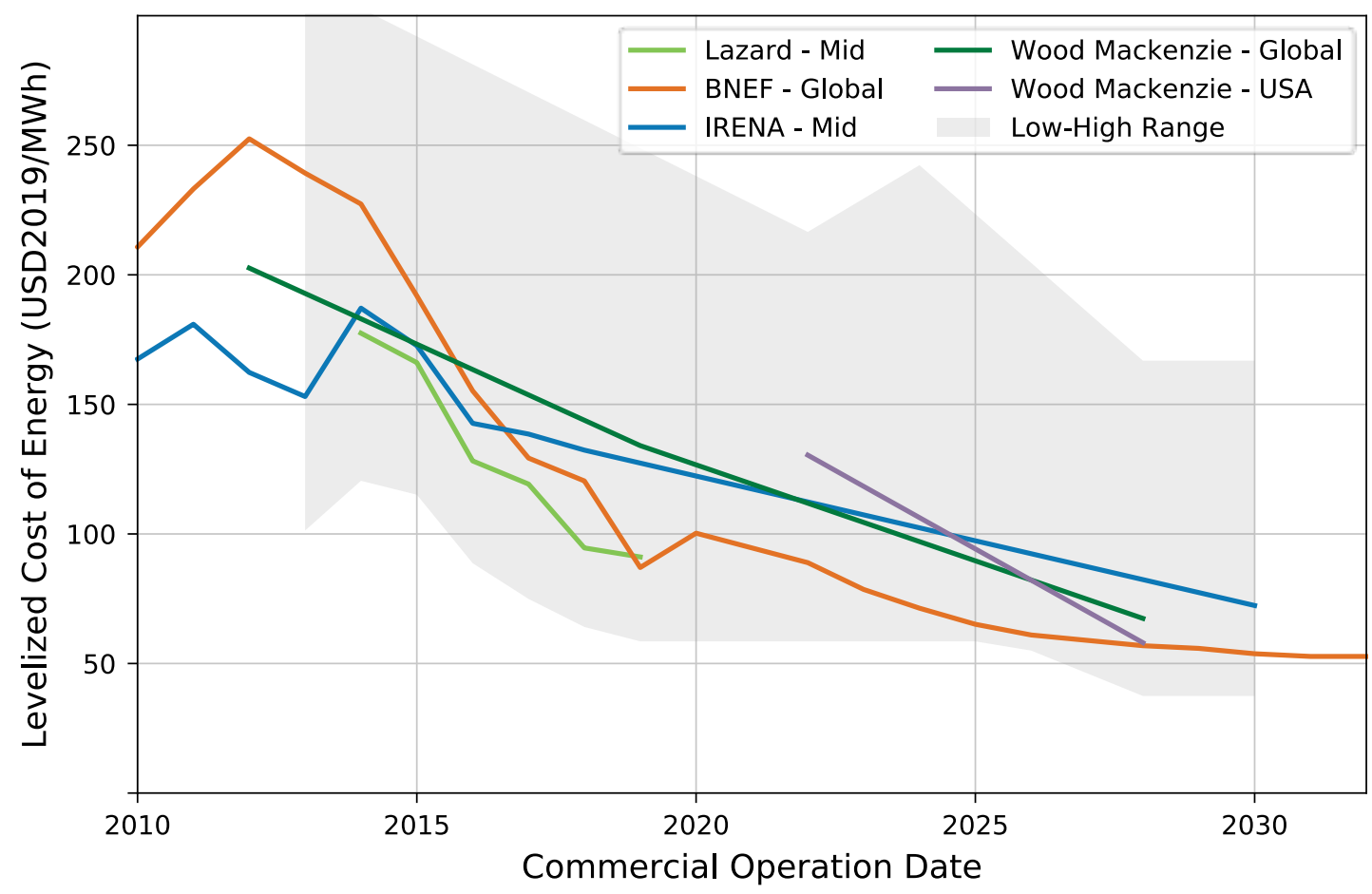

Note:

- "Low-High Range" indicates the lowest and highest LCOE estimate among the depicted literature sources.

- In the legend, "Lazard" refers to Lazard (2014, 2015, 2016, 2017, 2018, and 2019), "IRENA" to IRENA (2019), "Wood Mackenzie" to Yang et al. (2019), and "BNEF" to Brandily (2020).
- Estimates by industry analysts suggest global levelized cost of energy (LCOE) levels reaching between $\$ 50 / \mathrm{MWh}$ and $\$ 75 / \mathrm{MWh}$ by 2030, continuing a trend of declining LCOE estimates since 2012.

- In any given year, LCOE estimates from industry analysts vary, in part, because of differences in site characteristics (e.g., wind speed), regulatory contexts, calculation methods, and assumptions about offshore wind industry maturity and growth. 


\section{Capital Expenditures for Global Offshore Wind Projects}

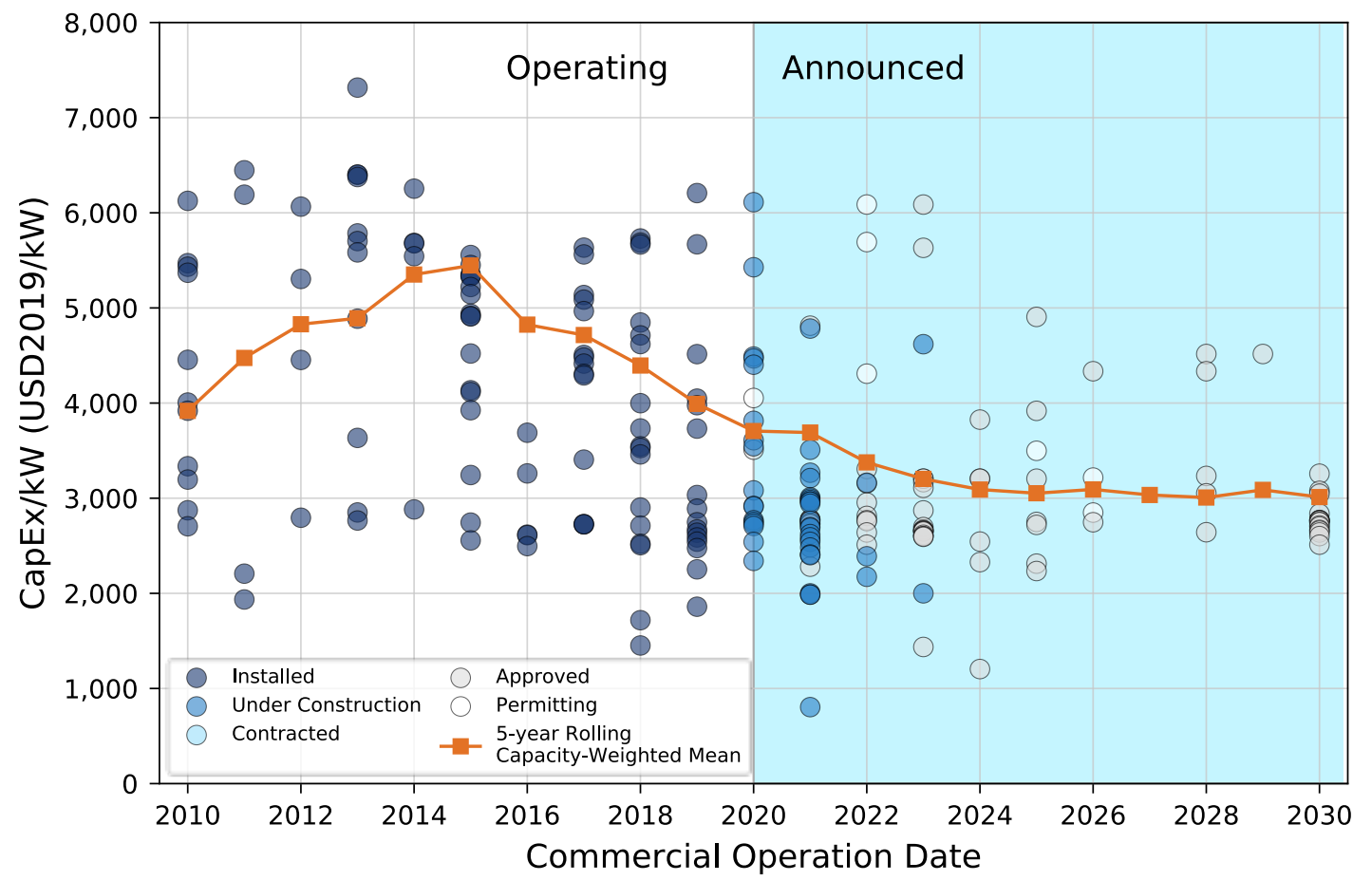

Note: CapEx data after 2020 as announced publicly by offshore wind developers (e.g., in corporate statements or press releases/reporting)
- Between 2019 and 2030, the capacityweighted 5-year rolling average of developer-announced capital expenditures (CapEx) declines by approximately 25\%; the rate of CapEx reductions decreases over this period.

- CapEx varies widely between projects each year because of differences in project siting characteristics, local supply chain maturity, deployed plant-scale and technology, and regulatory policy.

- Key drivers of CapEx decline include economies of scale from turbine and plant upsizing, technology innovation, increased experience, and a growing and more competitive supply chain.

- Turbine costs represent close to $30 \%$ of project CapEx. NREL estimates a turbine CapEx of approximately $\$ 1,300 / \mathrm{kW}$ for projects with a 2019 COD. 


\section{Global Offshore Wind Plant Operating Expenses}

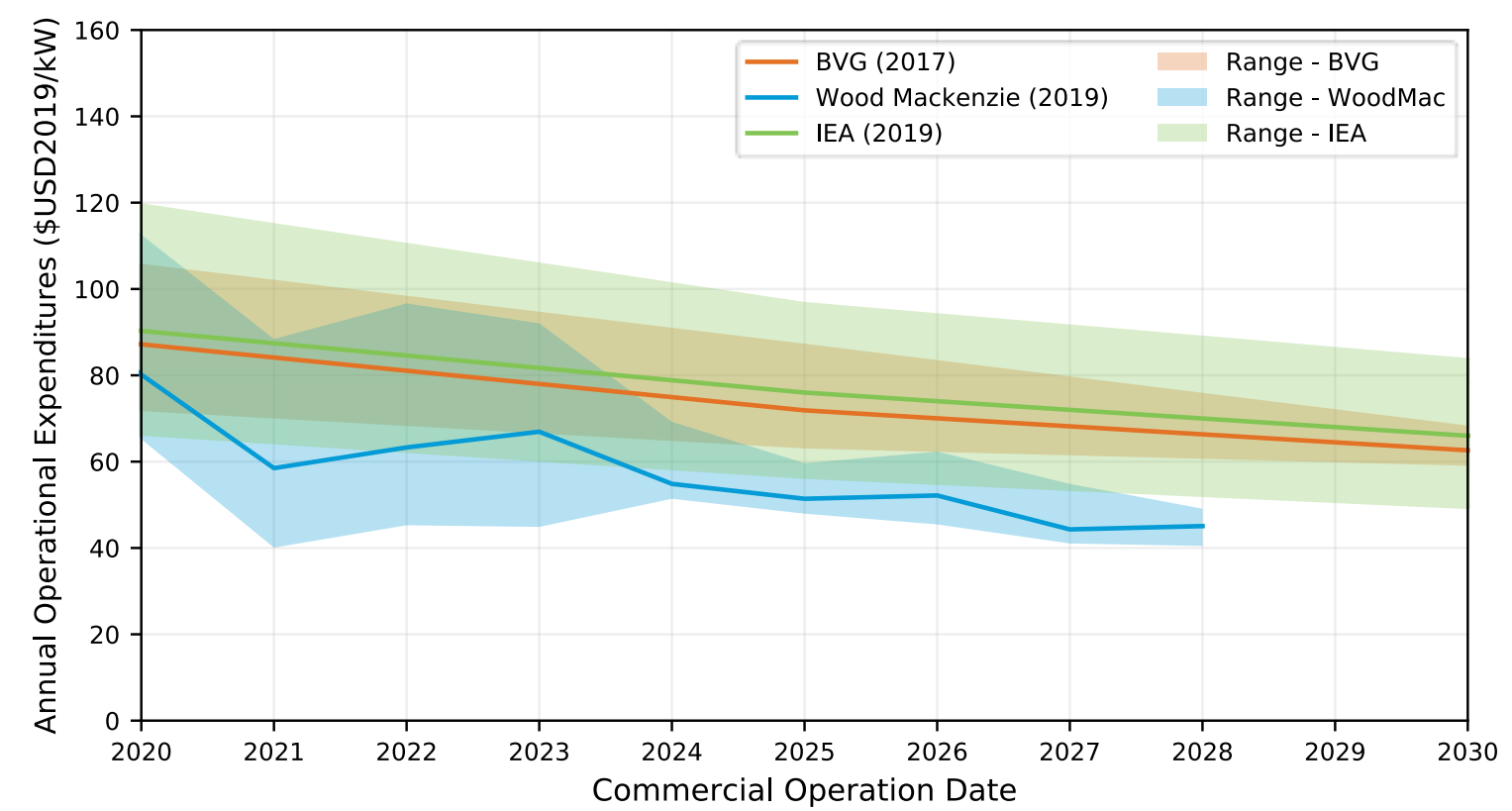

- Globally, industry analysts project that annual operational expenditures will decrease from approximately $\$ 100 / \mathrm{kW}$ in 2019 to less than $\$ 70 / \mathrm{kW}$ in the next decade.

- Technology advancements that contribute to the projected decrease in operational expenditures include:

- Increasing turbine capacity

- Increasing reliability

- Adoption of remote monitoring, inspection, and maintenance technologies

- Improvements in offshore access capabilities. 


\section{Offshore Wind Financing}

\begin{tabular}{|c|c|c|c|c|}
\hline Year & Coverage & $\begin{array}{c}\text { Debt/Sponsor Equity/Tax } \\
\text { Equity (\%) }\end{array}$ & $\begin{array}{l}\text { Pricing (Basis } \\
\text { Points) }\end{array}$ & Source \\
\hline 2006-2007 & Europe & $60 / 40 / 0$ & $150-200$ & Guillet (2018) \\
\hline 2009-2011 & Europe & $65 / 35 / 0$ & $300-350$ & Guillet (2018) \\
\hline 2012-2013 & Europe & $70 / 30 / 0$ & $200-250$ & Guillet (2018) \\
\hline 2014-2015 & Europe & $70 / 30 / 0$ & $200-250$ & Guillet (2018) \\
\hline 2016-2017 & Europe & $75 / 25 / 0$ & $150-225$ & Guillet (2018) \\
\hline 2018 & Europe & $70 / 30 / 0$ & $120-175$ & Guillet (2018) \\
\hline 2019 & United States & $50 / 20 / 30^{7}$ & $150-175$ & Norton Rose (2019) \\
\hline
\end{tabular}

- $\quad$ Access to low-cost capital for offshore wind projects continues into 2019 , consistent with a broader trend in renewable energy asset financing.

- $100 \%$ of European offshore wind projects with financial close in 2019 were project financed (i.e., nonrecourse) (Brindley 2020).

- U.S. financing is expected to be available at conditions similar to those in European offshore wind markets.

- The optimal debt-to-equity ratio in the United States is strongly influenced by the share of tax equity.

${ }^{5}$ Year 2008 not available from source (Guillet 2018). 


\section{Offshore Wind Financing - Tax Extenders Act}

\begin{tabular}{|c|c|c|c|c|}
\hline \multirow{2}{*}{$\begin{array}{c}\text { Start of } \\
\text { Construction/ } \\
5 \% \text { Safe } \\
\text { Harbor }^{8} \\
\text { [Four calendar } \\
\text { years } \\
\text { expiration] }{ }^{9}\end{array}$} & \multicolumn{2}{|c|}{$\begin{array}{c}\text { ITC level } \\
\text { (of total investment) }\end{array}$} & \multicolumn{2}{|c|}{$\begin{array}{c}\text { PTC level } \\
\text { (of } \$ 25 / \mathrm{MWh})^{10}\end{array}$} \\
\hline & $\begin{array}{c}\text { TEA } \\
(2019)\end{array}$ & Previous & $\begin{array}{c}\text { TEA } \\
(2019)\end{array}$ & Previous \\
\hline 2016 [2020] & $30 \%$ & $100 \%$ & $100 \%$ & $100 \%$ \\
\hline 2017 [2021] & $24 \%$ & $24 \%$ & $80 \%$ & $80 \%$ \\
\hline 2018 [2022] & $18 \%$ & $18 \%$ & $60 \%$ & $60 \%$ \\
\hline 2019 [2023] & $12 \%$ & $12 \%$ & $40 \%$ & $40 \%$ \\
\hline 2020 [2024] & $18 \%$ & $0 \%$ & $60 \%$ & $0 \%$ \\
\hline $2021[2025+]$ & $0 \%$ & $0 \%$ & $0 \%$ & $0 \%$ \\
\hline
\end{tabular}

On December 20, 2019, the Tax Extenders Act (TEA) was signed into law.

The TEA includes a 1-year extension of the production tax credit (PTC) and investment tax credit (ITC) for start of construction in 2020. The ITC or PTC effectively reduces the total project costs from a developer's/owner's perspective.

- The TEA changes incentivize projects with a construction start in 2019 to explore re-qualifying for higher levels (18\% [ITC] and 60\% [PTC]) stipulated for construction start in 2020.

Offshore wind projects may choose to elect the ITC or PTC, depending on the relative financial value (e.g., capital costs and expected capacity factor) and risk. The ITC is generally more favorable for offshore projects.

Notes:

${ }_{8}$ The $5 \%$ Safe Harbor Rule stipulates that a project must incur at least $5 \%$ of the total cost of the facility to satisfy the "begin construction" requirement of the ITC/PTC and prove a "continuous program of construction" or "continuous efforts to advance towards completion of the facility" (Internal Revenue Service [IRS] 2013).

${ }^{9} \mathrm{~A}$ facility meets the Safe Harbor Rule if it is placed in service 4 calendar years from the calendar year during which construction began (IRS 2013). Also note that on May 27, 2020, the IRS issued Notice 2020-41, providing a 1-year extension to the Continuity Safe Harbor for projects that began construction in 2016 or 2017 (IRS 2020).

10 On June 5, 2019, the IRS released a notice increasing the PTC to reflect inflation from \$24/MWh to \$25/MWh (IRS 2019). 
References 


\section{References}

\section{Primary Database Sources}

- $\quad$ 4C Offshore. 2019. Offshore Wind Farms Intelligence. http://www.4coffshore.com/windfarms/request.aspx?id=owfdb.

- $\quad$ 4C Offshore. 2020. Global Offshore Wind Farms Intelligence. http://www.4coffshore.com/windfarms/request.aspx?id=owfdb.

- BloombergNEF. 2019. 2H 2019. Offshore Wind Market Outlook. https://about.bnef.com/.

- BloombergNEF. 2020. 1H 2020 Offshore Wind Market Outlook. https://about.bnef.com/.

- MAKE Consulting. 2018. Global Offshore Wind Power Project Database. http://www.consultmake.com/research/databases.

- $\quad$ WindEurope. 2019. Offshore Wind in Europe: Key trends and statistics 2018. https://windeurope.org/about-wind/statistics/offshore/european-offshore-wind-industrykey-trends-statistics-2018/. 


\section{References}

Beiter, P. W. Musial, L. Kilcher, M. Maness, A. Smith. 2017. An Assessment of the Economic Potential of Offshore Wind in the United States from 2015 to 2030 (Technical Report). Golden, CO. National Renewable Energy Laboratory. NREL/TP-6A20-67675.

https://www.energy.gov/sites/prod/files/2019/09/f66/2018\%200ffshore\%20Wind\%20Technologies\%20Market\%20Report.pdf.

Beiter, Philipp, Jenny Heeter, Paul Spitsen, David Riley. 2020. Comparing Offshore Wind Energy Procurement and Project Revenue Sources Across U.S. States (Technical Report). Golden, CO: National Renewable Energy Laboratory. NREL/TP-5000-76079.

https://www.nrel.gov/docs/fy20osti/76079.pdf.

Brandily, Tifenn. 2020. Levelized Cost of Electricity 1H 2020: Renewable Chase Plunging Comodity Prices. BloombergNEF. April 28, 2020. https://www.bnef.com/core/lcoe?tab=Forecast\%20LCOE.

Brindley, G. 2020. Financing and investment trends. WindEurope. https://windeurope.org/wp-content/uploads/files/aboutwind/reports/Financing-and-Investment-Trends-2019.pdf.

BVG Associates. 2017. Future renewable energy costs: Offshore wind. InnoEnergy. https://bvgassociates.com/wpcontent/uploads/2017/11/InnoEnergy-Offshore-Wind-anticipated-innovations-impact-2017_A4.pdf.

BVG Associates. 2019. Global offshore wind market report, 2019. Prepared on behalf of Norwegian Energy Partners. https://www.4subsea.com/wp-content/uploads/2020/01/Offshore-Wind-market-report-2019-Norwep.pdf.

Gaertner, Evan, Jennifer Rinker, Latha Sethuraman, Frederik Zahle, Benjamin Anderson, Garrett Barter, Nikhar Abbas, Fanzhong Meng, Pietro Bortolotti, Witold Skrzypinski, George Scott, Roland Feil, Henrik Bredmose, Katherine Dykes, Matt Shields, Christopher Allen, and Anthony Viselli. 2020. Definition of the IEA 15-Megawatt Offshore Reference Wind. Golden, CO: National Renewable Energy Laboratory. NREL/TP-5000-75698. https://www.nrel.gov/docs/fy20osti/75698.pdf. 


\section{References}

Guillet, Jerome. 2018. "Who Will Fund US Offshore Wind - and on what terms?" Presented at the Offshore Wind Implementation Summit, Teaneck, New Jersey, September 7, 2018. https://green-giraffe.eu/presentations/who-will-fund-us-offshore-wind\%E2\%80\%93-and-what-terms.

Hundleby, Giles, Kate Freeman, Andy Logan, and Ciaran Frost. 2017. "Floating Offshore: 55 Technology Innovations That Will Have Greater Impact on Reducing the Cost of Electricity from European Floating Offshore Wind Farms." KiC InnoEnergy and BVG Associates. http://www.innoenergy.com/new-floating-offshore-wind-report-55-technology-innovations-that-will-impact-the-Icoe-infloating-offshore-wind-farms/.

International Energy Agency. 2019. World Energy Outlook 2019. https://www.iea.org/reports/world-energy-outlook-2019.

International Renewable Energy Agency (IRENA). 2019. Future of Wind; Deployment, investment technology, grid integration and socio-economic aspects (A Global Energy Transformation paper). https://www.irena.org/Lmedia/Files/IRENA/Agency/Publication/2019/Oct/IRENA Future of wind 2019.pdf.

Internal Revenue Service (IRS). 2013. Notice 2013-29. https://www.irs.gov/pub/irs-drop/n-13-29.pdf

IRS 2019. Notice 84 FR 26508. https://www.govinfo.gov/content/pkg/FR-2019-06-06/pdf/2019-11810.pdf

IRS. 2020. Notice 2020-41. https://www.irs.gov/pub/irs-drop/n-20-41.pdf 


\section{References}

Lazard. 2014. Lazard's Levelized Cost of Energy Analysis - Version 8.0.

https://www.lazard.com/media/1777/levelized_cost_of_energy___version_80.pdf.

Lazard. 2015. Lazard's Levelized Cost of Energy Analysis - Version 9.0. https://www.lazard.com/media/2390/lazards-levelized-cost-ofenergy-analysis-90.pdf.

Lazard. 2016. Lazard's Levelized Cost of Energy Analysis - Version 10.0. https://www.lazard.com/media/438038/levelized-cost-ofenergy-v100.pdf.

Lazard. 2017. Lazard's Levelized Cost of Energy Analysis - Version 11.0. https://www.lazard.com/media/450337/lazard-levelized-costof-energy-version-110.pdf.

Lazard. 2018. Lazard's Levelized Cost of Energy Analysis - Version 12.0. https://www.lazard.com/media/450784/lazards-levelizedcost-of-energy-version-120-vfinal.pdf.

Lazard. 2019. Lazard's Levelized Cost of Energy Analysis - Version 13.0. https://www.lazard.com/media/451086/lazards-levelizedcost-of-energy-version-130-vf.pdf.

Musial, W., D. Heimiller, P. Beiter, G. Scott, and C. Draxl. 2016. 2016 Offshore Wind Energy Resource Assessment for the United States (Technical Report). Golden, CO. National Renewable Energy Laboratory. NREL/TP-5000-66599.

http://www.nrel.gov/docs/fy16osti/66599.pdf. 


\section{References}

Musial, W., P. Beiter, P. Spitsen, J. Nunemaker, V. Gevorgian. 2019a. 2018 Offshore Wind Technologies Market Report. U.S. Department of Energy Office of Energy Efficiency and Renewable Energy. DOE/GO-102019-5192. https://www.nrel.gov/docs/fy19osti/74278.pdf.

Musial, W. P. Beiter, J. Nunemaker, D. Heimiller, J. Ahmann, J. Busch. 2019b. Oregon Offshore Wind Site Feasibility and Cost Study (Technical Report). Golden, CO. National Renewable Energy Laboratory. NREL/TP-500-74597.

https://www.nrel.gov/docs/fy20osti/74597.pdf.

Musial, W., P. Beiter, J. Nunemaker. 2020. Cost of Floating Offshore Wind Energy Using New England Aqua Ventus Concrete Semisubmersible Technology (Technical Report). Golden, CO. National Renewable Energy Laboratory. NREL/TP-5000-75618. https://www.nrel.gov/docs/fy20osti/75618.pdf

National Grid. 2019. National Grid Electricity System Operators technical report. https://www.ofgem.gov.uk/publications-andupdates/ofgem-has-published-national-grid-electricity-system-operator-s-technical-report.

Norton Rose. 2019. Edited transcript of 2019 American Wind Energy Association conference panel discussion with Henrik Dordrup ( $\varnothing$ rsted).

Taxpayer Certainty and Disaster Tax Relief Act of 2019 (part of the Consolidated Appropriations Act [H.R. 1865]).

U.S. Coast Guard. 2020. The Areas Offshore of Massachusetts and Rhode Island Port Access Route Study. Docket Number USCG-2019-0131.https://www.navcen.uscg.gov/pdf/PARS/FINAL_REPORT_PARS_May_14_2020.pdf. 


\section{References}

WindEurope. 2018. Floating Offshore Wind Energy: A Policy Blueprint for Europe. https://windeurope.org/wpcontent/uploads/files/policy/position-papers/Floating-offshore-wind-energy-a-policy-blueprint-for-Europe.pdf.

Wiser, R. K Jenni, J. Seel, E. Baker, M. Hand, E. Lantz, A. Smith. 2016. Forecasting Wind Energy Costs \& Cost Drivers - The Views of the World's Leading Experts. LBNL-1005717. Lawrence Berkeley National Laboratory. https://eta-

publications.lbl.gov/sites/default/files/lbnl-1005717.pdf.

Wood Mackenzie. 2019. Offshore wind operations and maintenance trends 2019. https://www.woodmac.com/reports/power-marketsoffshore-wind-operations-and-maintenance-trends-2019-301033.

Wood Mackenzie 2020. Global Wind Turbine Supply Chain Trends 2020. https://www.woodmac.com/reports/power-markets-globalwind-turbine-supply-chain-trends-2020-399666.

Yang, S., S. Lassen, R. Kragelund. Global bottom-fixed offshore wind LCOE. 28 October 2019. Accessed through Wood Mackenzie subscription services. https://www.woodmac.com/ 


\section{Notice and Acknowledgments}

This work was prepared, in part, by the National Renewable Energy Laboratory, operated by Alliance for Sustainable Energy, LLC, for the U.S. Department of Energy (DOE) under Contract No. DE-AC36-08G028308. Funding provided by the U.S. Department of Energy Office of Energy Efficiency and Renewable Energy Wind Energy Technologies Office. The views expressed in the work do not necessarily represent the views of the DOE or the U.S. Government. The U.S. Government retains and the publisher, by accepting this work for publication, acknowledges that the U.S. Government retains a nonexclusive, paid-up, irrevocable, worldwide license to publish or reproduce the published form of this work, or allow others to do so, for U.S. Government purposes.

The preparers of these slides would like to acknowledge contributions from Tiffany Byrne, Brian Smith, Paul Veers, Eric Lantz, John Frenzl, and Sheri Anstedt (NREL); Patrick Gilman, Dan Beals, Liz Hartman, and Gary Norton (DOE); Jeff Kehne (Magellan Wind); Kris Ohleth ( $\varnothing$ rsted); Tom Harries (BNEF); James Glennie (Danish Trade Council/Embassy); Necitas Sumait and Stephen Boutwell (BOEM); Brandon Burke and Liz Burdock (Business Network for Offshore Wind); Adam Stern (Offshore Wind California); and Juergen Pilot (National Offshore Wind R\&D Consortium). 


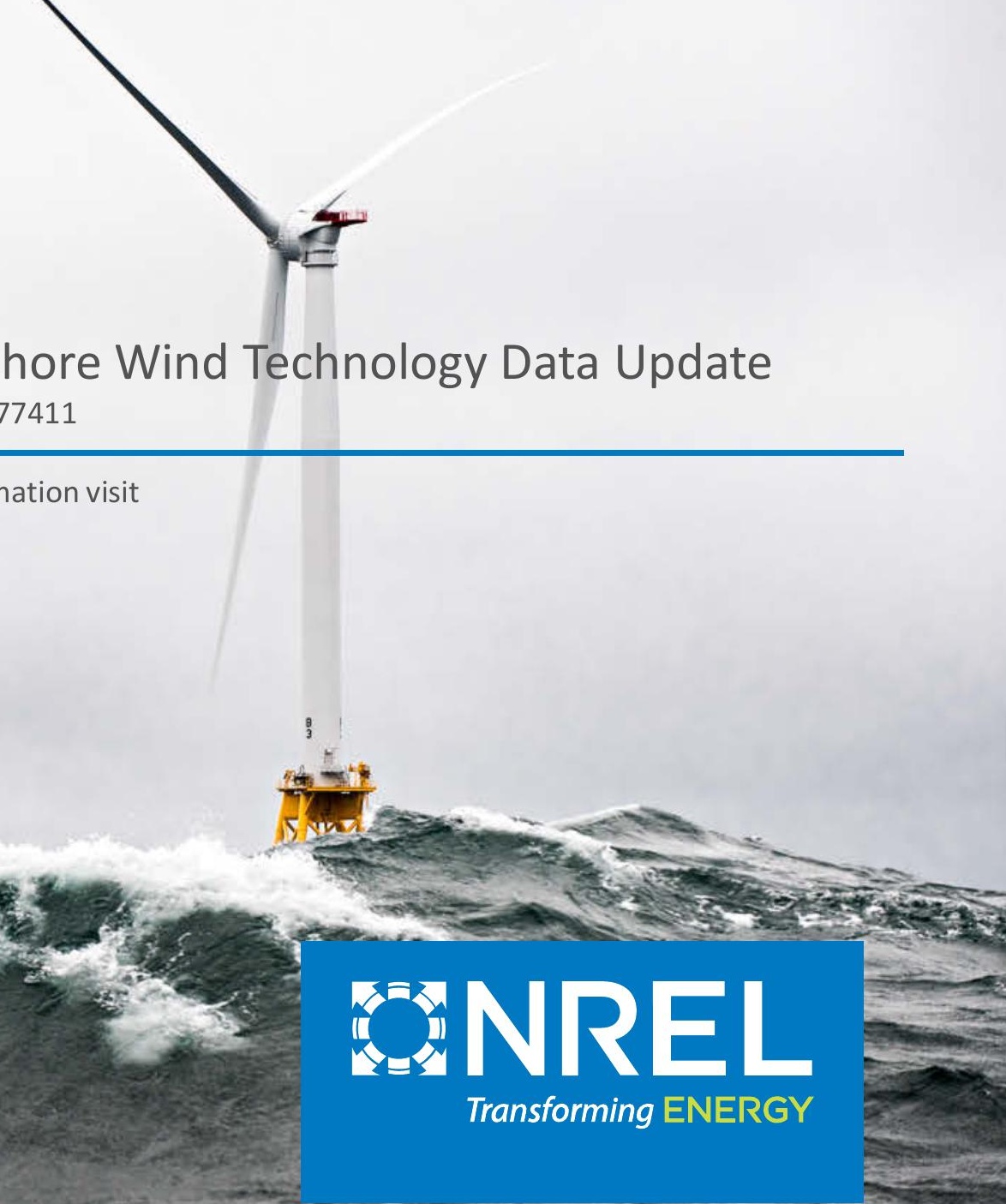

